413

\title{
LA-5834-MS
}

Informal Report

UC-41 and UC-71

Reporting Date: December 1974

Issued: August 1975

\section{Rover Shipping Cask}

by

\author{
Betty Lobb
}

Horace E. Noyes

David R. Smith 
In the interest of prompt distribution, this report was not edited by the Technical Information staff.

Printed in the linited States of America. Available from National Technical Information Service

1. S. Department of Commerce 5285 Port Royal Hoad Springfiekl. VA 22151

Price: Printed Cops \$is.45 Microfiche \$2.25

This report was prepared as an account of work sponsored bv the United Statey Government. Neither the United States nor the Uniled States Energy Research and Development Adminintrution, nor any of their enployees, nor any of their contractors. subcontractors, or their employees. makes any warranty, express or implied, of aswumes any legal ligbility or any information, epparatus, product, or procens disclosed, or reprearnts that its use would not infringe priveleby oweded 
ROVER SHIPPING CASK

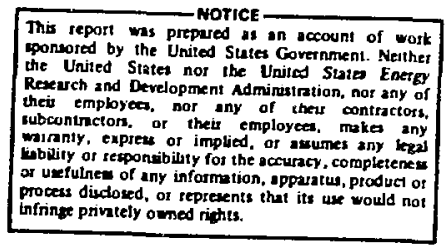

by

Betty Lobb, Horace E. Noyes, and David R. Smith

ABSTRACT

A large well-shielded shipping container, commonly known as the Rover cask, has been designed to accommodate fuel elements from the Rover and TORY IIC reactors in compliance with existing regulatory requirements. Background material and approvals are given in the Appendixes.

\section{INTRODUCTION}

The shipping container is a steel-jacketed lead-filled cask weighing approximately 17.7 tonnes (39000 1b). Fuel from the Rover and TORY IIC reactors, currently stored at the Nevada Test Site of the Energy Research and Development Administration, will be shipped to the Idaho Chemical Processing $P$ lant in the Rover cask within a cask insert designed by Group J-6 (LASL-NTS). The 1.37-m (54-in.)-long insert consists of a 5 by 5 square array of 76.2-mm (3-in.) o.d. by 0.508-mm (0.020-in.)wall steel tubes in a welded aluminum box. The regions between the tubes are packed with boron carbide and are sealed at each end by a poured epoxy plug. The 25 steel tubes may be loaded with Rover fuel in cardboard tubes or TORY IIC fuel in welded aluminum tubes. These inner arrangements are for the convenience of the processing plant. The Rover fuel will go into an incinerator, whereas the TORY IIC fuel starts its reprocessing in a disselver.

To demonstrate compliance with existing regulatory requirements, the background materfal and approvals are given in the Appendixes.

\section{ROVER FUEL CASK DESIGN CRITERIA}

The authorized packaging censists of a rectangular, lead-filled, steel-jacketed weldment, which conforms to DOT Specification 55, providing a $254 \mathrm{~mm}$ (10-in.) lead shielding thickness and a minimum of 9.52-m (3/8-in.) steel-jacket thickness. The inner cavity dimensions are 406 by $406 \mathrm{~mm}$ by $1.57 \mathrm{~m}$ (16 by 16 by 62 in.) and the gross weight is approximate1y 7.7 tonnes $(39000 \mathrm{lb})$.

The cask, identified as Model No. AL-L8, is described in Los Alamos Scientific Laboratory (LASL) Drawings ENG E-374 (Rev. F) R1, D2, and D3.

The allowable contents include Rover fuel elements and other fissile and radioactive materials in special form. When used for shipping more than 15 Rover fuel elements, all loaded elements will be in boron-poisoned cask inserts (Drawing 34Y43605 E2, LASL Drawing 530030, and insert Drawings 34Y-31474 D1-D7, or equivalent). Insert. closures will use gaskets of silastic or other material of equivalent high-temperature capability. Fuel element: sot in these cask inserts will be encapsulated to comply with special form criteria.

Fast reactor fuel fins may be packaged in an insert with a single length of 128-mm (5-in.)-diam. schedule 40 steel pipe with threaded or Silastic gasketed flanged closure. The total fissile material loading for this configuration will not exceed 75 $\mathrm{g} / \mathrm{cm}$ of pipe length.

For shipping ${ }^{233} \mathrm{u}$ or plutonium bearing material, the atomic ratio of boron to ${ }^{233} \mathrm{U}$ or plutonium wil! be at least twice the ratio of boron to ${ }^{235} \mathrm{U}$ normally 
provided for the loaded Rover fuel element cask inserts, which is a factor of 2 greater than calculated to provide a $k_{\text {co }}$ less than unity.

These considerations dictate a maximum of $60 \mathrm{~kg}$ of ${ }^{235} \mathrm{U}$ or $30 \mathrm{~kg}$ of ${ }^{233} \mathrm{u}$ or plutonium. Mixtures of fissile materials shall be so limited that the number of kilograms of ${ }^{235} \mathrm{U}$ divided by 60 , plus the

number of kilograms of plutonium and ${ }^{233} \mathrm{U}$ divided by 30, will not exceed unity.

The closure derice includes holes for a security seal Insertion in the Iid channel and cask lid gulde pins in each end. The security seals must be affixed betore shipment.

To facilitate underwater loading, the cask is equipped with a drain line which is to be closed with a fusibie plug.

STRUCTURAL ANALYSIS

The structural analysis of the shipping container is attached as Appendix A.

\section{QUALITT ASSURANCE}

Quality assurance specifications are attached as Appendix B.

\section{RADIOLOGICAL SAFETY}

Shielding calculations are attached as Appendix c.

THERMAL ANALYSIS

The thermal anaiysis is attached as Appendix D.

NUCLEAR CRITICALITY SAFETY ANALYSIS

The nuclear criticality safety analysis is attached as Appendix E.

ENERGY RESEARCH AND DEVELOPMENT ADMINISTRATION

The Certificate of Approval issued by the Operational Safety Division, Albuquerque Operations Office, ERDA, identified as USA/5645/BLF (ERDA-AL) is attached as Appendix F.

CONTAINER DRAWINGS

Isometric drawings of the cask and of several cask inserts are provided in Appendi 6 . These present needed information for prospective users of the cask. Structural and fabrication details may be obtained from the LASL Drawings ENG-E-374 (Rev. F), R1, D2, and D3 for the cask. LASL Drawings ENG-E$530030 \mathrm{Rl}, 31474 \mathrm{DI}-\mathrm{D} 7$ and $34 \mathrm{Y}-31474 \mathrm{E} 2$ present fabrication information for cask inserts. 
Introduction

This appendix presents the structural analysis applicable to the Rover cask.

The analysis is to demonstrate compliance with Sec. II, Packaging Standards, of ERDAM 0529 Safety Standards for Packaging of Radioactive and

Fissile Materials.

The analysis is numbered to correspond to Sec. II of 0529 , and sumarizes the mathematical analysis presented as an appendix. 
STRUCTURAL ANALYSIS OF THE ROVER SHIPPING CASK

(Numbers refer to ERDAM 0529)

II.A.1. The cask and cask insert materials have demonstrated compataiflity through more than $10 \mathrm{yrs}$. of service. No significant chemical, gaivanic, or uther reactions have occurred or would be expected to occur.

II.A.2. The cast lid is secured to the body in an extremely rugged $f_{i}$ shicn so that inadvertent opening is not possible. Also, double security seals provide positive indication that the cask has not been opened.

II.A.3.a. The container which will be handled by forklift or by crane, weighs approximately 17.7 tonnes $(39,000 \mathrm{lb})$. Design calculations indicate that the lifting devices car support three times the cask weight without exceeding the yield strengtr. of the material (Sheets 12 and 13).

II.A.3.B. Calculations on sheet 14 show that the lid lifting devices are edequate.

II.A.3.C. Not applicable.

Ii.A.3.d. Failure of the lifting device would in no way affect the containment or shielding properties of the package.

II.A.4. This container has no built-in tie-down devices.

II.B.1. Beam load resistance is more than adequate. (See calculatloss, Sheet 15)

II.B.2. An external pressure of $175 \mathrm{kPa}$ is a trivial condition for this shipping cask. 
11. C. Criticality standards are discussed in Appendix E.

II.D.1. See Appendix E.

I.D.2. The package has been evaluated independent of the transport vohicle.

II.D.3. No deviations from requirements are necessaxy.

11.E. There will be no compromise of the integrity of the container or its contents as defined in Annex 1. Normal Conditions of Transport. Following is a summary of the findings of the calculations for the normal conditions of transport(Appendix, Annex 1):

1. HEAT: At $55^{\circ} \mathrm{C}$, no part of the cask will in an" way be affected.

2. $C O L D$ : An ambient temperature of $-40^{\circ} \mathrm{C}$ in st 111 air and shade presents no problem to tilis container.

3. PRESSURE: The sealis used in this container are extreme pressure and temperature seals. Pressures of $1 / 2$ atm. are completely insignificant in this application.

4. VIBRATION: ThIs shipping consainer is not susceptible to vibiaticn darage.

5. LATER SPRAY: The container seal will preclude enery of :... molscure into the container.

6. FREE DROP: A free drop of $1.22 \mathrm{~m}(4 \mathrm{ft})$ is much less than tr: accident condtion requirements and will not compromise the integrity of the container.

7. CORWER DROP: Not applicable.

8. PENETRATION: This test is trivial for this package.

9. CORPRESSION: Not applicable. 
11.F. Calculations indicate the containment capabllities of this container would not be impared when subjucted to the accident condttons spectfied. Thete would be ne release of radioactive matertal and no unacceptable changes in radiation dose rates external to the container.

Following is a sumaty of the hypothetteal accident cest condition calculations in lieu of actual test:

1. FREE DROP: The most Aamaging ortentation of the cast for the $9.14 \mathrm{~m}(30-(\mathrm{l})$ crop test is assumed to be such that the cask impacts on a corner with the center of gravity directly above the point of impact

The lid attachment has been rodified as show tn the cast: drawing Revision $F$ so that the design has nore $t:$ mple atrength to retaln thr l1d for any drop orienca: : Gaiculations are show on Sinculs 17 rimoegh 20.

$\therefore$ PUNCTURE: The analyses to sfmulate a test of droping tho cask on a $152.4 \mathrm{~mm}$ (6 in.) dian. rod from a he i... n? 1.01 . (40 in.) Indicates distortion but no failure of the sted jacket. The drop was assumed onto a flat side of the containet (Sheets ( through 11).

3. Thergat: The thermal analysis, performed in 1969, is attacher as Appenis: 2 . This evaluation, coupled with r. : isation (3) of the kadiological Calculations (Appendiz C). denonstrati: rhat exposure to the standard fire wh 11 not conrosise the shieldini capability of the cask.

4. WATER IMLERSION: The radioactive contents would not be released as a result of water Immersion; criticality safety evaluations have been based on assumed optimum moderation. 
Shipping container:

Lead filled --See LASL Ordwinn ENG-E-374

Properties:

Lad:

$$
\begin{aligned}
T y & =4 \times 5 i \text { (Static), yield siress } \\
E & =2 \times 10^{6} \text {. modulus of elasticity }
\end{aligned}
$$

Stee 1:

$$
\begin{aligned}
\sigma_{V} & =35 \mathrm{ksi} \text { (Static) } \\
F_{L i t} & =65 \mathrm{ksi} \text { (Static) } \\
E & =30 \times 10^{6}
\end{aligned}
$$

Lead strenoth under impact loading subjected to high strain rate nay br expressed as:

$$
v=\int_{0}^{R} u \frac{d r}{d t}+c \text { where } c \text { is a constant }
$$

depending upon the static characteristics of lead and $\mu$ is the viscosity coefficient of a newtonian liquid. On previous test's using lead blocks as energy absorbers, rap -3 has obtained dynamic resistances of lead up to $9 \mathrm{ksi}$. These cylindrical lead test specimens were free to Jeform laterally and subjected to drop heights conparable to the shipping container under consideration. These tests give evidence that one will have conservative results if the velocity term is Jropped and with this possible error of $100^{\circ}$ on the conservative side the calculations are made. The results are not to show the exact amount of deformation expected. rather they will show the maximum nossible deformation due to the loadina condition chosen. 


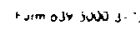

LOS ALAMOS SCIENTIFIC LABORATORY - ENGINEERING DEPT

ENGINEERING CALCULATIONS

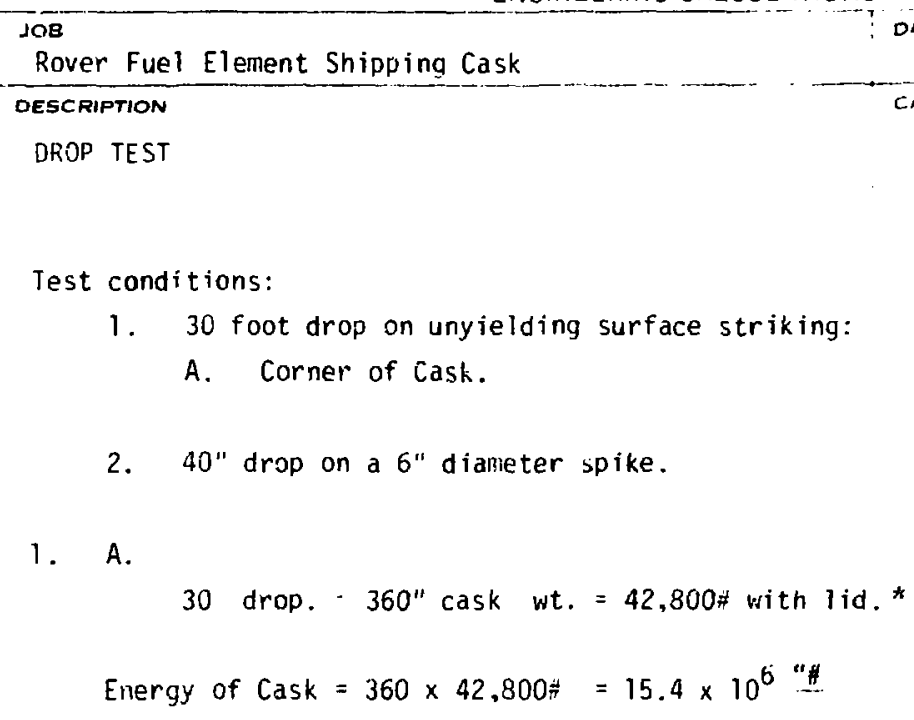

1. 30 foot drop on unyielding surface striking:

A. Corner of Cask.

2. 40" drop on a 6" diameter spike.

1. A.

30 drop. - $360^{\prime \prime}$ cask wt. $=42,800 \#$ with lid. *

Energy of Cask $=360 \times 42,800^{*}=15.4 \times 10^{6} \mathrm{AH}$

Neglecting the bulging effect will produce somewhat less contact area than one would actually get during a drop but with the steel jacket as confinenent material the bulging is difficult to estimate.

${ }^{*}$ Calculations are based on a cask we1ght of $42,800 \%$. Th1s provides conservative results for the actual cask. 


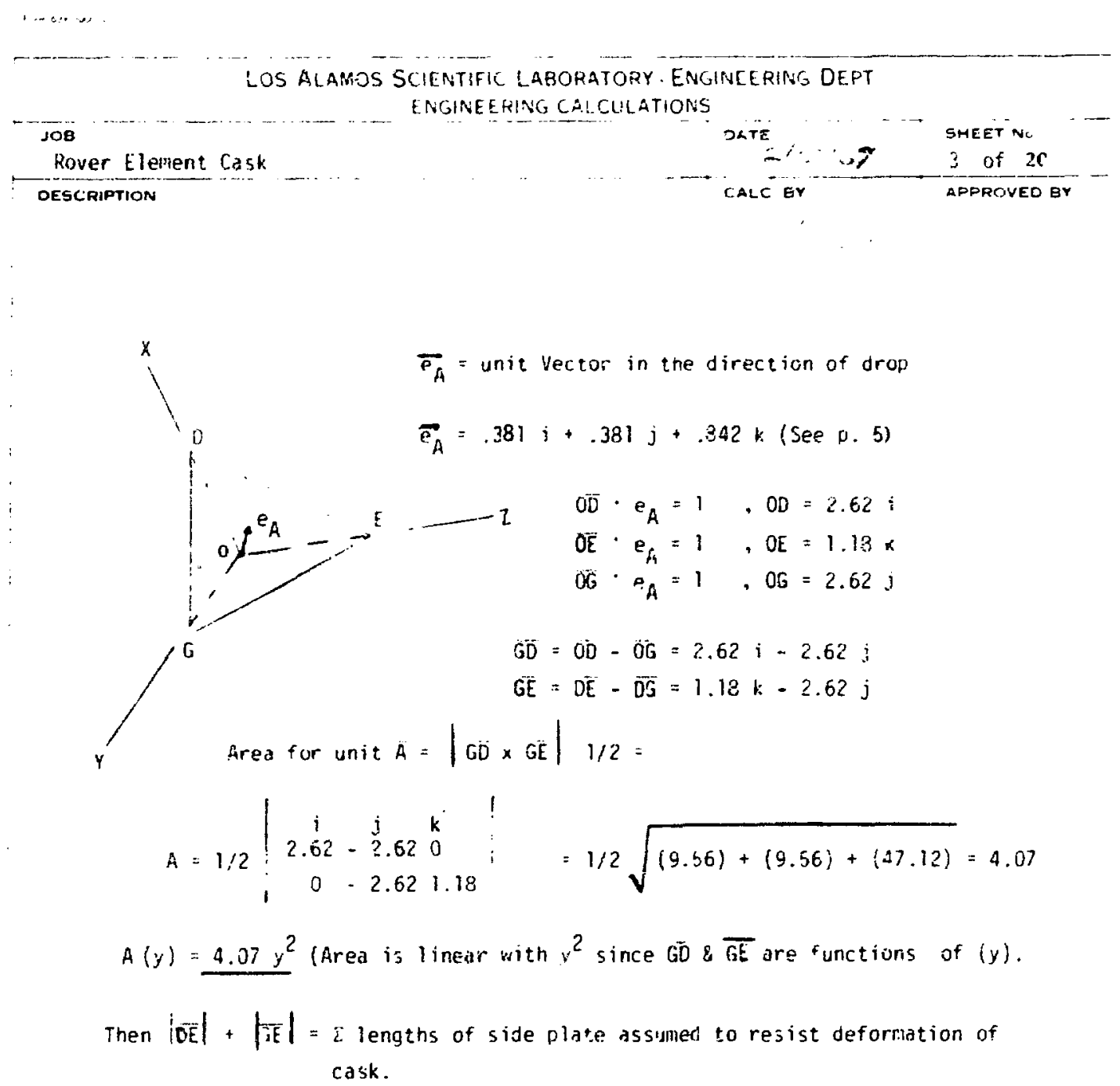

$\left|{ }_{D E}\right|=|\bar{G}|=2.87^{\prime \prime}$ for unit $\mathrm{A}$.

$\therefore L=2(2.87) y=5.74 y$

Energy absorbed by lead $=E_{L}=4000 \int_{0}^{y_{m}} 4.07 y^{2} d y=5427 r_{n i}^{3}$

Energy of side plates $=60,000(3 / 3) \int_{y}^{y_{m}} 5.74$ ydy $=64,575 y_{\mathrm{m}}^{2}$

$\begin{aligned} & \text { Energy of angles } \\ & \text { Area of } L s=5.72\end{aligned}=60,000(5.72) \int_{0}^{1.18 \mathrm{dy}}=404,976 \mathrm{y}_{\mathrm{m}}$ 
$f_{2}, m 0.10300002-i 3$

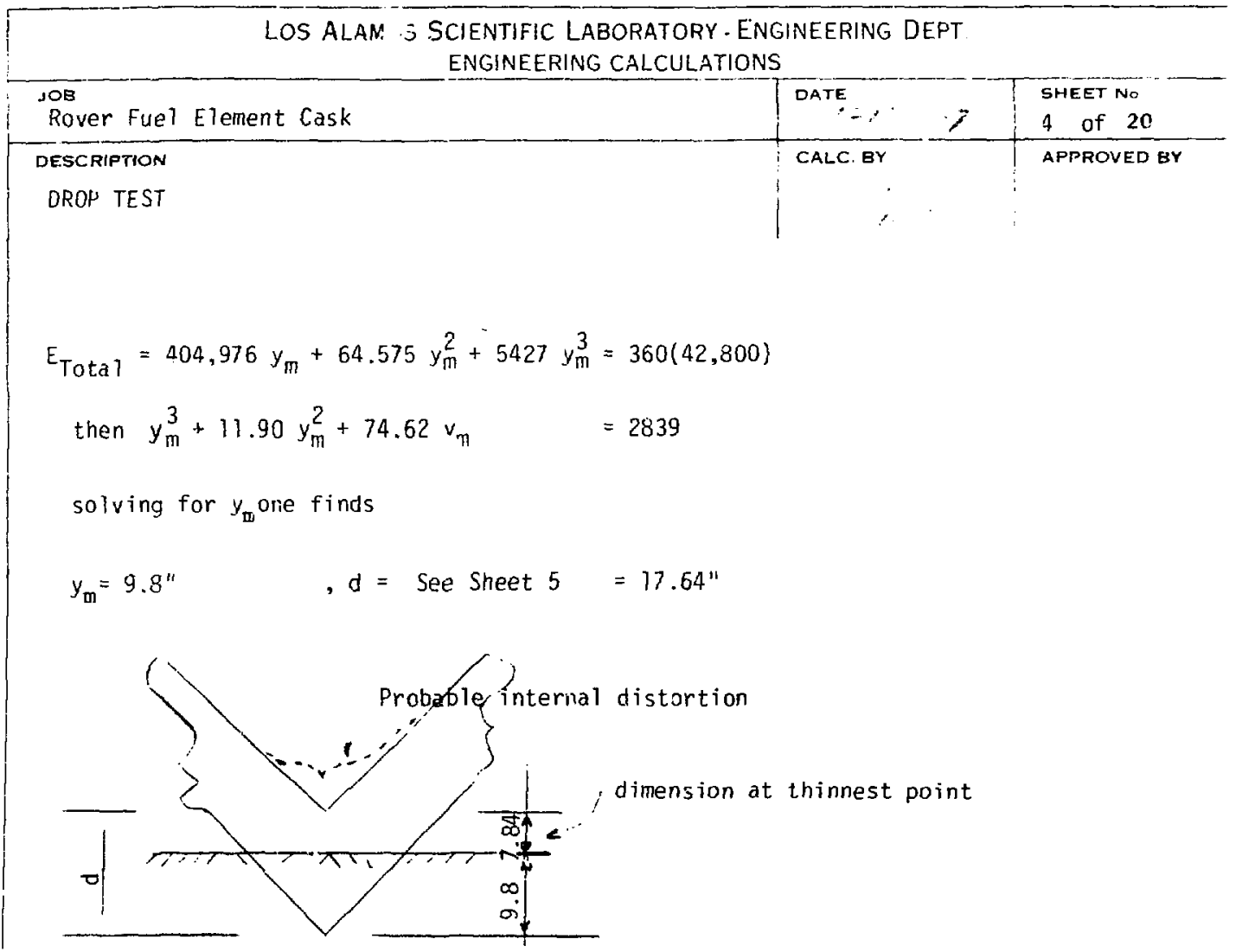

One could expect some internal distortion or the inner linex due to this corner drop, this would be desirable for loss of shielding prevention but will cause high stresses in the inner jacket.

Due to the extremely large deformation of the outer jacket, cracks will probably develop at the weld joints. There is no calculation that will accurately predict this event and the crack development is purely an opinion of the author.

A drop on the top corner would cause the lid to become deformed and the container seal would probabiy be destroyed permitting water to enter the container. 


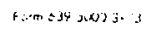

LOS ALAMOS SCIENTIFIC LABORATORY. ENGINEERING DEPT. ENGINEERING CALCULATIONS

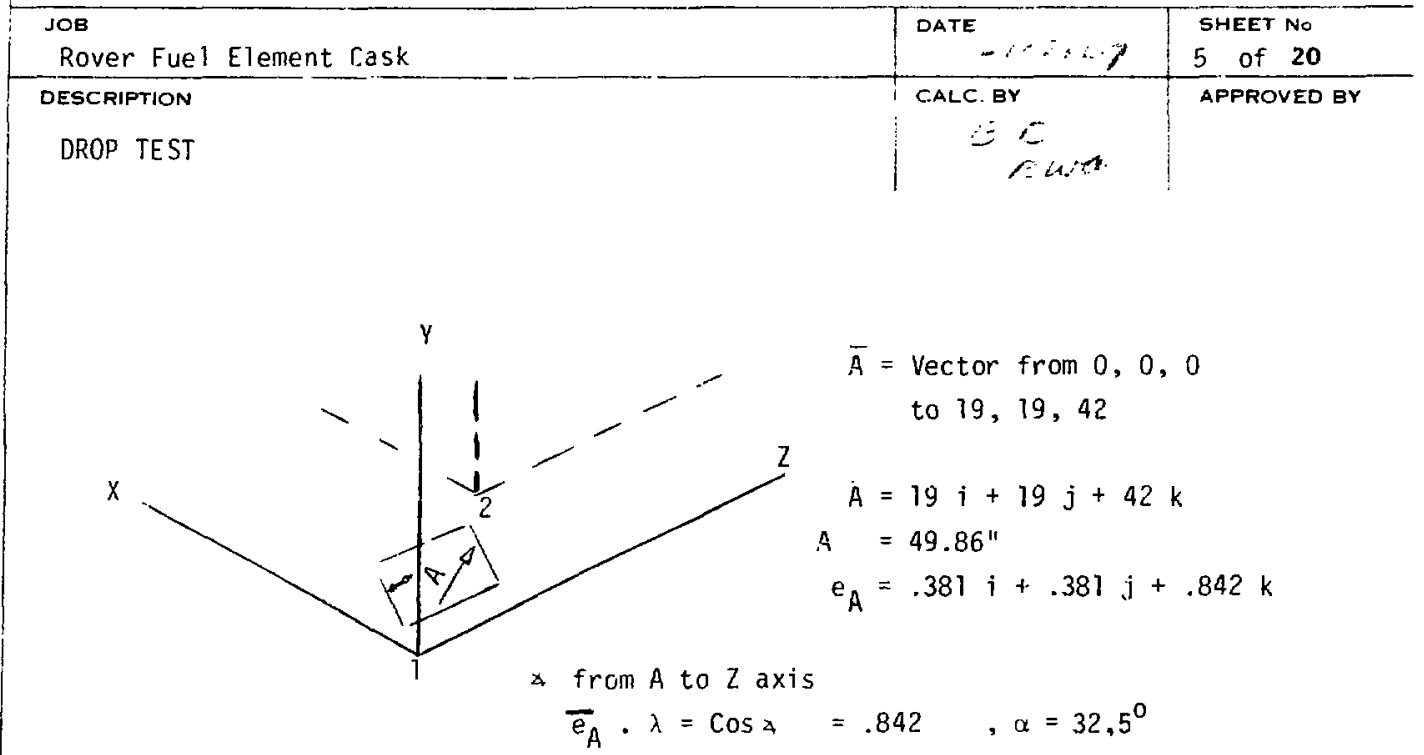

$\mathrm{C}=$ Vector from pts. 1 to 2

0 , 0 , o to $11,11,11$ (Assume 11" wal1s)

$\bar{c}=11 j+11 j+11 k$

$d=$ projection of $\bar{C}$ upon $A=1$ distance along $A$ from plane through 1

$d=c \cdot e_{A}=(11 i+11 j+11 k)^{\text {to plane through pt. } 2}(381 i+.381 j+.842 k)=17.34 "$ 
Form $639500013-73$

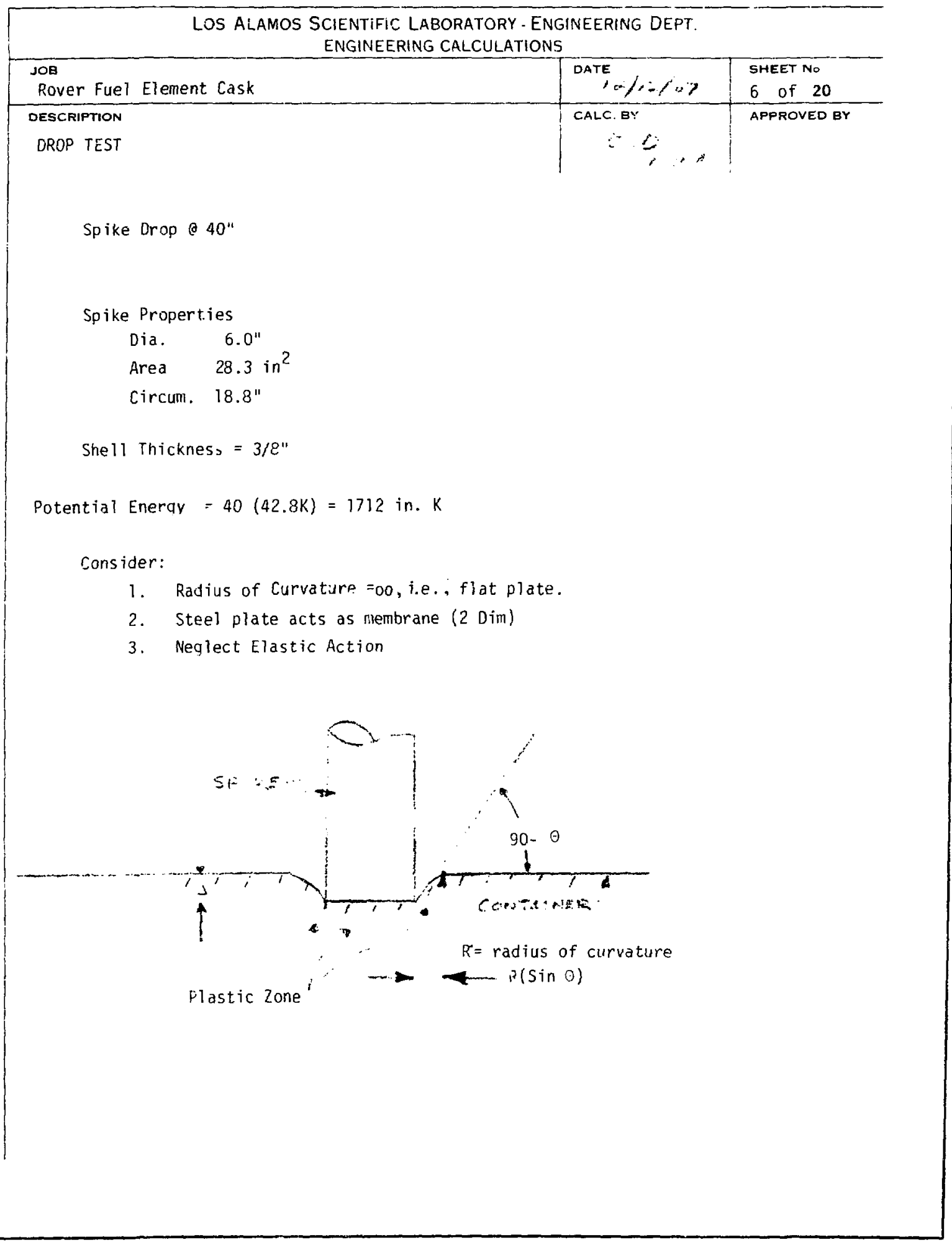


Faen 839500003.3

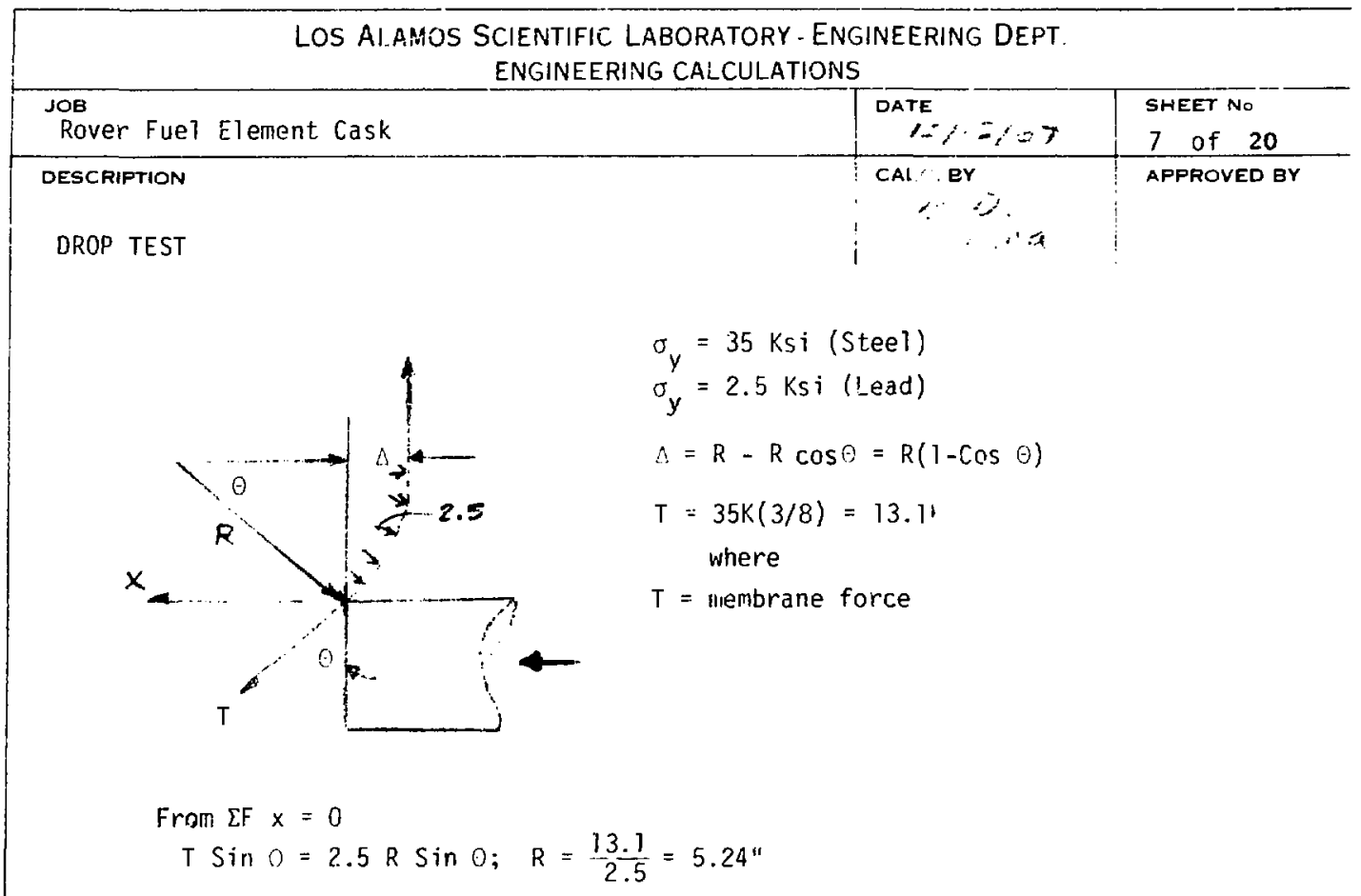

Since the material is not flexible the radius will increase slightly, use the conservative value of 5.24 .

Energy absorption is a function of the lead, plate $\hat{\alpha} \triangle$.

(1) Plate

$$
\begin{aligned}
E p 1=f\{(13.1 \sin \theta) \Delta\}, \text { where } \theta & =f(\Delta) \\
=\int_{0}^{\Delta} F(\Delta) d \Delta ; F(\Delta)=T \sin \theta, \Delta=R(1-\cos \theta) & \\
\frac{\Delta}{R}-1=-\operatorname{Cos} 0, \cos \theta & =\left(1-\frac{\Delta}{R}\right) \\
& =\left(1-\frac{\Delta}{5.24}\right) \\
\theta_{f} & =\operatorname{Cos}^{-1}\left(1-\frac{\Delta}{5.24}\right) \\
F(\Delta) & =T \sin \left[\cos ^{-1}\left(1-\frac{\Delta}{5.24}\right)\right]
\end{aligned}
$$




$$
\begin{aligned}
& \text { Foom } 6595000 \text { 3-73 } \\
& \text { LOS ALAMOS SCIENTIFIC LABORATORY . ENGINEERING DEPT. } \\
& \text { ENGINEERING CALCULATIONS } \\
& E \mathrm{pL}=1290 \int_{0} \sin ^{2} \theta d \theta=1290\left(\frac{\theta}{2}-\frac{\sin 2 \theta}{4}\right) \\
& =1290\left[\frac{\theta}{2}-\frac{\sin 2 \theta}{4}\right]_{0}^{\theta}=1290\left(\frac{\theta}{2}-\frac{\sin 2 \theta}{4}\right)
\end{aligned}
$$

\begin{tabular}{|c|c|c|}
\hline $\begin{array}{l}\text { JOB } \\
\text { Rover Fuel Element Cask }\end{array}$ & $\begin{array}{l}\text { DATE } \\
\qquad, ;, \infty\end{array}$ & $\begin{array}{l}\text { SHEET No } \\
8 \text { of } 20\end{array}$ \\
\hline $\begin{array}{l}\text { DESCRIPTION } \\
\text { DROP TEST }\end{array}$ & 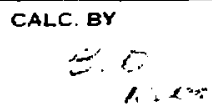 & APPROVED BY \\
\hline
\end{tabular}

(2) Lead

E Lead $=28.3(2.5) \Delta=70.7 \Delta$

$$
1712=70.7 \Delta+1290\left[\frac{\theta}{2}-\frac{\operatorname{Sin} 2 \theta}{4}\right] \quad\left(E_{\text {Potential }}=E_{\text {Lead }}+E_{\text {plate }}\right)
$$

$\operatorname{Try} \Delta=5.2$

$$
\begin{aligned}
& 0=\cos ^{-1}\left(1-\frac{5.2}{5.24}\right)=\operatorname{Cos}^{-1}(.0076) \\
& \Theta=89.55^{\circ} \\
& \frac{\rho}{2}=\frac{1.668}{2}=.834
\end{aligned}
$$

$\frac{\operatorname{Sin} 2 \theta}{4}=\frac{\operatorname{Sin} 179.1}{4}=.00393$ 
Fam $0.3450003-73$

\begin{tabular}{|c|c|c|}
\hline \multicolumn{3}{|c|}{$\begin{array}{l}\text { LOS ALAMOS SCIENTIFIC LABORATORY - ENGINEERING DEPT. } \\
\text { ENGINEERING CALCULATIONS }\end{array}$} \\
\hline $\begin{array}{l}\text { JoB } \\
\text { Rover Fuel Element Cask }\end{array}$ & DATE $=\angle: \because,>$ & $\begin{array}{l}\text { SHEET No } \\
9 \text { of } 20\end{array}$ \\
\hline $\begin{array}{l}\text { DESCRIPTION } \\
\text { DROP TEST }\end{array}$ & 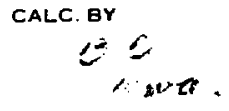 & APPROVED BY \\
\hline
\end{tabular}

$1712=376.6+1290(.834-.00393)$

$1712 \neq 1447.4$

Since 0 approaches $90^{\circ}$ and the equation is not satisfied, it appears the spike will puncture the cask.

At this point elongation is:

$R \operatorname{Sin} \Theta=5.24 \sin 89.55^{\circ}=5.23$

$R \theta=5.24\left(\frac{89.55}{57.3}\right)=5.17$

$\%$ Elongation $=100\left(\frac{8.17-5.23}{5.23}\right)=100 \quad\left(\frac{2.94}{5.23}\right)=56.28$

The steel shell will yield before the $90^{\circ} \star$ is attained.

Find $\Delta \quad$ allowable $30 \%$ elongation.

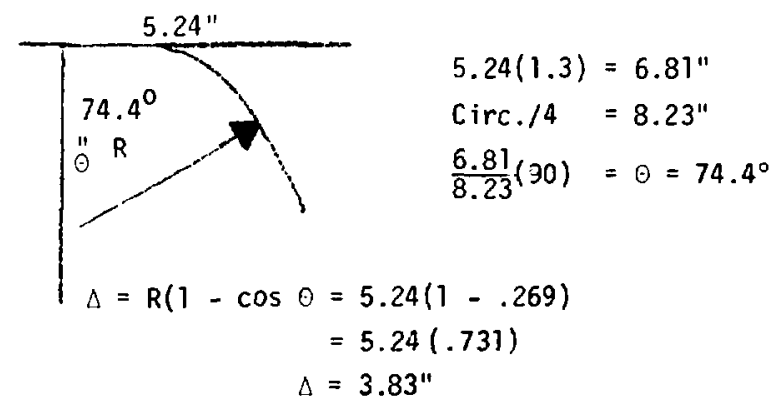

Assume the distance of yielding occurs for only $1 \mathrm{R}$ from the spike.

The steel plate fails at $3.83^{\prime \prime}$ of puncture and the lead must absorb

the remaining energy. 
Fism $03950003+13$

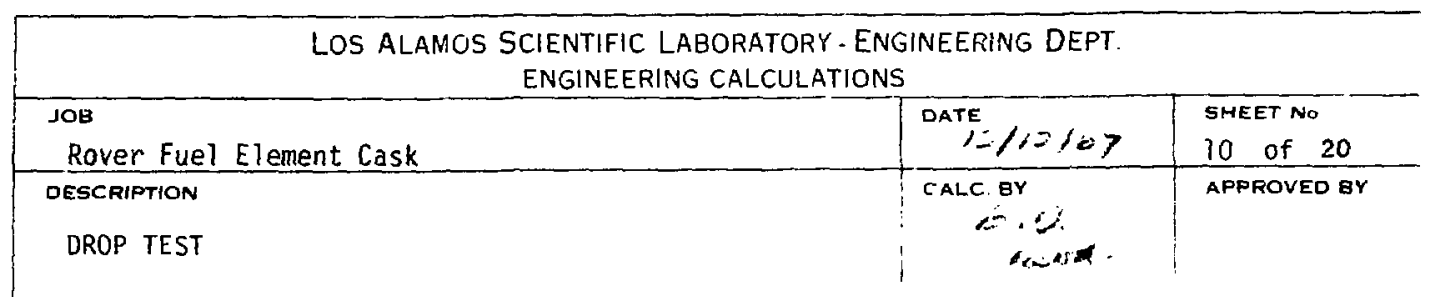

Since puncture occurs recalculate $R$ and the corrected $\Delta$ for the ultimate strength of steel $60 \mathrm{ksi}$.

$\therefore \quad T=60 \mathrm{~K}(3 / 8)=22.5 \mathrm{~K}$

$\&$

$R=\frac{T}{2.5}=\frac{22.5}{2.5}=9.00^{\prime \prime} \quad\left(\Sigma F_{x}=0\right.$, See page 7$)$

Yield will occur e $0=74.4^{\circ}$

\& again assume all yielding will occur within $1 R$ of spike.

So find $E$ oL absorbed for $74.4^{n}$ if that is less than 1712 the steel plate fails and the rest of the energy is absorbed by the lead.

$$
E \mathrm{pl}=\int_{0}^{0} \mathrm{RT} \operatorname{Sin}^{2} \operatorname{od} \theta \quad \text { (See page } 8 \text { ) }
$$

where $T=22.5(18.8)=423 \mathrm{~K}$

$R T=9(423)=3807$

$$
\begin{aligned}
E \mathrm{pL} & =3807\left[\frac{0}{2}-\frac{\sin 20}{4}\right]^{0=74.4^{\circ}} \\
& =3807\left(\frac{74.4}{57.3}-\frac{\sin 148.8}{4}\right) \\
& =3807(.652-.130) \\
E \mathrm{pL} & =3807(.522)=1987 \mathrm{in.K} \text { Steel plate will not fail at ultimate of } 60 \mathrm{ksi}
\end{aligned}
$$


F $3903950003-73$

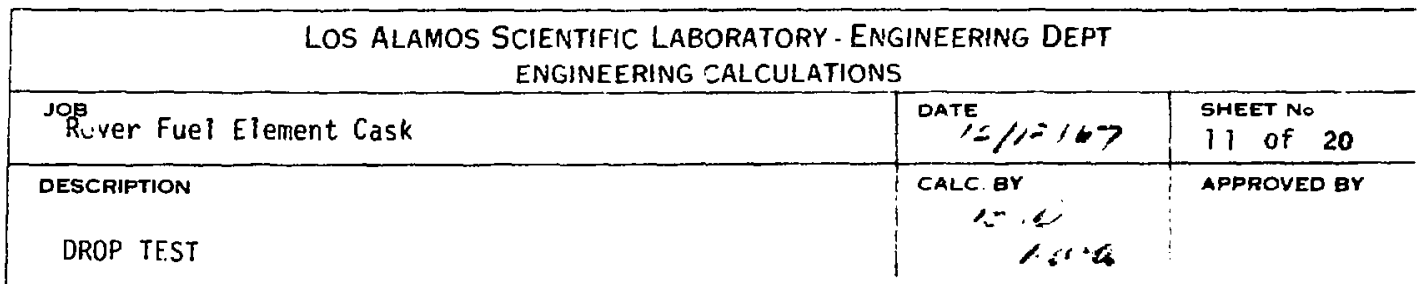

So now set $E \mathrm{pL}=1712$ \& solve for new $O \& \Delta$.

$1712=3807\left[\frac{\theta}{2}-\frac{\sin \geq \theta}{4}\right]$
where,

$\theta=\cos ^{-1}\left(1-\frac{\Delta}{9}\right)$

\& $E_{\text {Lead }}=28.3(4) \Delta=113.2 \Delta$

$\therefore \quad 171=113.2 \Delta+3807\left[\frac{\theta}{2}-\frac{\sin 20}{4}\right]$

Try $\Delta=4.5^{\prime \prime}$

$\theta=\cos ^{-1}\left(1-\frac{4.5}{9}\right)=\cos ^{-1}(.5)=60^{\circ}$

$\frac{O}{2}=\frac{\frac{60}{57.3}}{2}=\frac{1.047}{2}=.5 \hat{z} 3$

$\frac{\sin 20}{4}=\frac{\sin 120^{\circ}}{4}=\frac{.865}{4}=.217$

$1712=113.2(4.5)+3807(.523-.217)$

$=510.7+1164.9$

$1712=1675.6$

$\therefore \quad \theta=60^{\circ} \& \quad \Delta=4.5^{\circ}$

$R \sin O=9.00\left(\sin 60^{\circ}\right)=7.79$

$R O=9.00\left(\frac{60}{57.3}\right)=9.42$

$\%$ Elongation $=100\left(\frac{9.42-7.79}{7.79}\right)=100\left(\frac{1.63}{7.79}\right)$

$=20.9 \%$ 
f sim ost suld ins

IOS ALAMOS SCIENTIFIC LABORATORY - ENGINEERING DEPT ENGINEERING CALCULATIONS

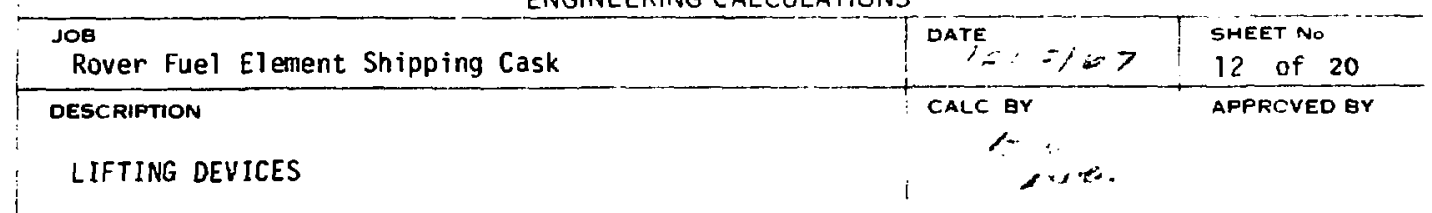

Art II Section 3 a. AEC Appendix 0529

Package lifting devices must withstand $3 \times$ wt. without yielding.

$W t=42000$

Test $u 1 t=T W=126 \underline{\text { kips }}$

4 lugs are provided - assume vertical component of force $=126 / 4=31.5^{k}$

each lug. Loads perpendicular to this direction will depend upon the sling or other device used.

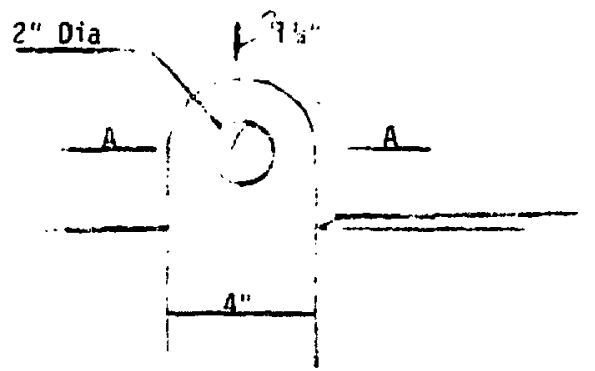

Net Area Section A-A

$A_{A A}=(4-2) 1.25=2.5\left[{ }^{\prime \prime}\right.$

$\sigma=\frac{31.5}{2.5}=12.6 \mathrm{ksi}$ (tension) ok

Net Section at eye

4x: $\mathrm{pL}$

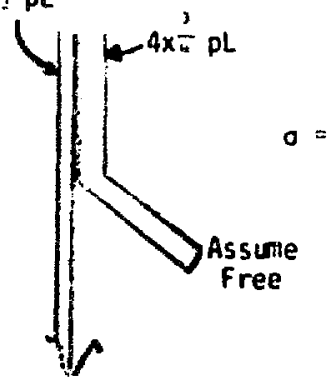

Hext assume the $4 x_{2}: \mathrm{pl}$ carries all load:

$0=\frac{31.5}{2}=15.75 \mathrm{ksi} \quad$ ok

Hote that this is not likely to happen

- however the lift device is still sound. 


\begin{tabular}{|c|c|c|}
\hline \multicolumn{3}{|c|}{$\begin{array}{c}\text { LOS ALAMOS SCIENTIFIC LABORATORY - ENGINEERING DEPT. } \\
\text { ENGINEERING CALCULATIONS }\end{array}$} \\
\hline $\begin{array}{l}\text { JoB } \\
\text { Rover Fuel Element Cask }\end{array}$ & DATE & $\begin{array}{l}\text { SHEET NO } \\
13 \text { of } 20\end{array}$ \\
\hline $\begin{array}{l}\text { DESCRIPTION } \\
\text { LIFTING DEVICE }\end{array}$ & 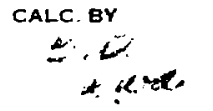 & APPROVED BY \\
\hline
\end{tabular}

Assume a single lift point cable sling is used to lift the cask, whose individual lengths are 11.5 feet (This is a description at the actual system used) then loads produced on the lifting lugs are as follows:

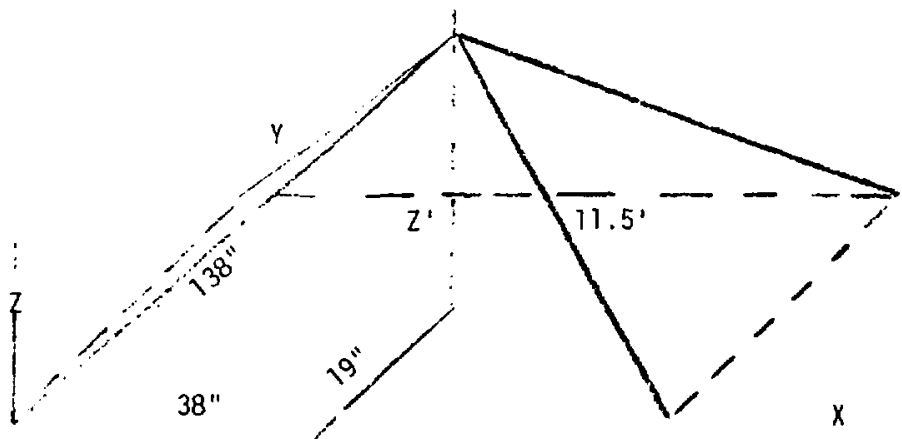

$$
z^{\prime}=\sqrt{(133)^{2}-(19)^{2}-(38)^{2}}=131.2^{\prime \prime}
$$
$\cos ^{\theta} x=.275$
$F_{2}=31.5 \mathrm{~K}$
$M_{2}=0$
$\cos \theta_{y}=.138$
$F_{y}=4.58 K$
$\cos \theta_{2}=.949$
$F_{x}=9.13 \mathrm{~K}$
$M_{x}=3 r_{y}=13.74^{\mu} \mathrm{K}$

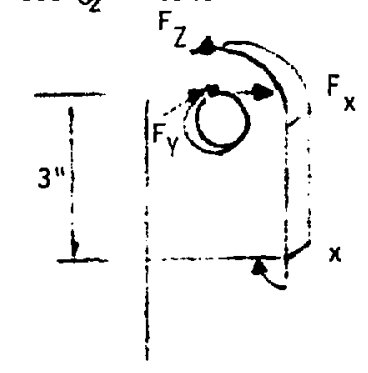

Ease properties

Area $=4.0(1.25)=5.0 \mathrm{in} .^{2}$

$I_{x}=\frac{1}{12}(4)(1.25)^{3}=.651$ in. $^{4}$
$I y=\frac{1}{12}(1.25)(4)^{3}=6.67$ in. $^{4}$

a max nomal $=\frac{31.5}{5}+\frac{27.39(2)}{6.67}+\frac{13.74(.625)}{.651}=27.7 \mathrm{ksi}$

Shear $=1.5 \frac{\rho}{A}=1.5(9.13) / 5=2.74 \mathrm{Ksi}$ and $1.37 \mathrm{Ksi}$

With the above sling arrangement stresses less than yield result with $3 x$ Wt applied. 
Form $83950003-7$

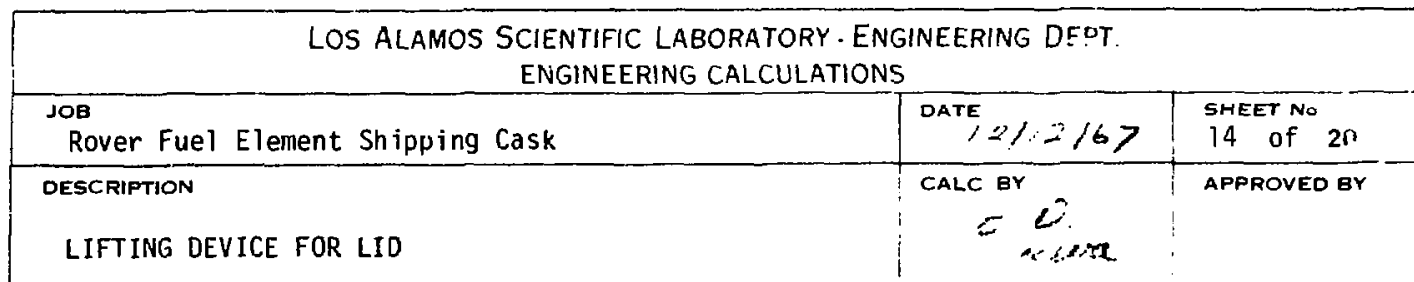

By standard rigging practice the lid lifting device could not be used to lift the entire cask, therefore, one may check stresses produced by the factored weight of the lid only.

Stresses developed when lifting the lid are as follows:

Weld attaching the 6112.5 beam to the lid

$\sigma=\frac{6000(3)}{2 L}=\frac{6000 \leqslant 3)}{2(67)}=134$ pounds $/ 7$ inear inch.

A minimum size weld will carry this load.

No other stresses need be considered silice the member is attached along its entire length; and by observation one may approve the bearing stresses developed on the surface at the lifting holes. 
faim osy $3000 \mathrm{an}$

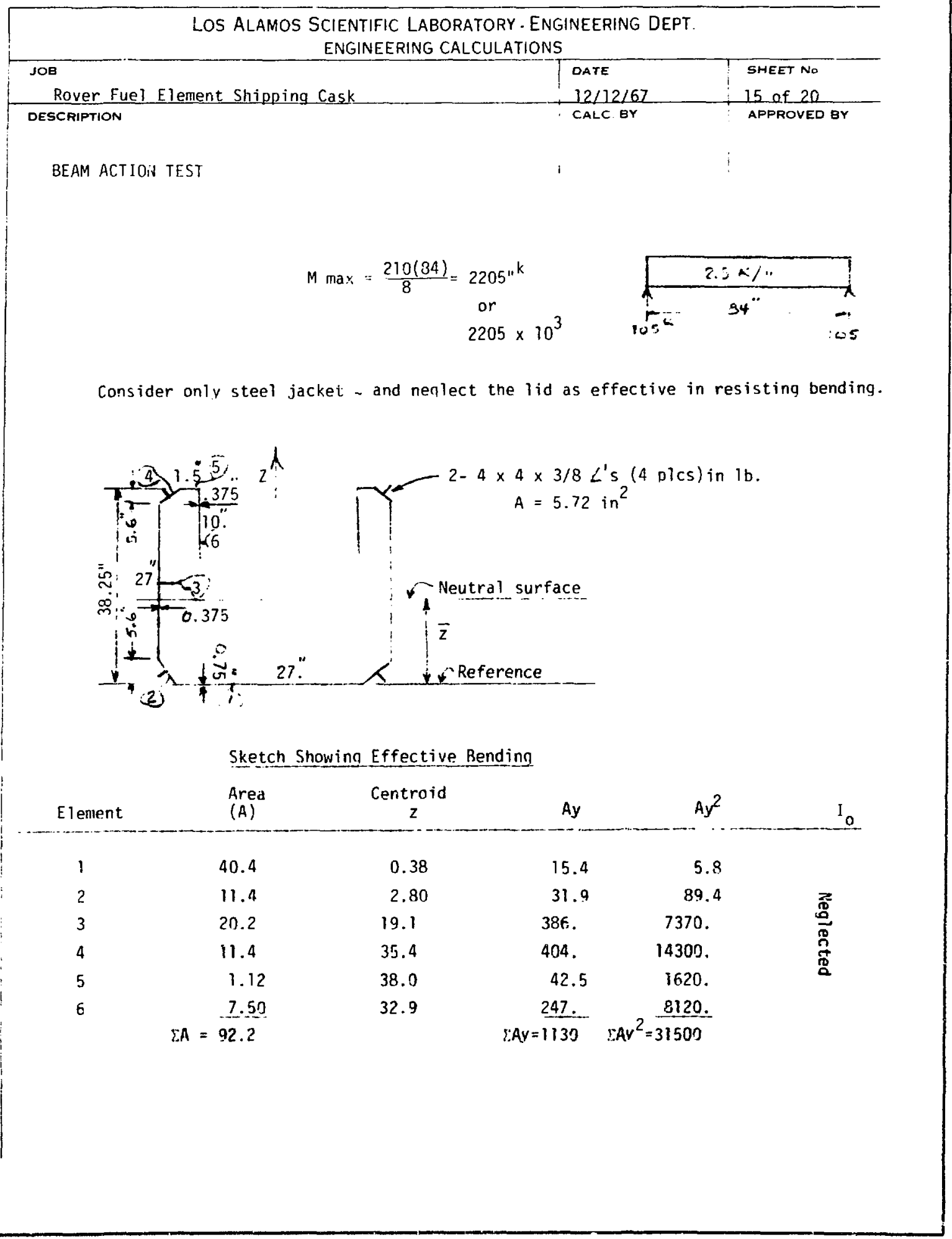


Form 0.395000 3-7

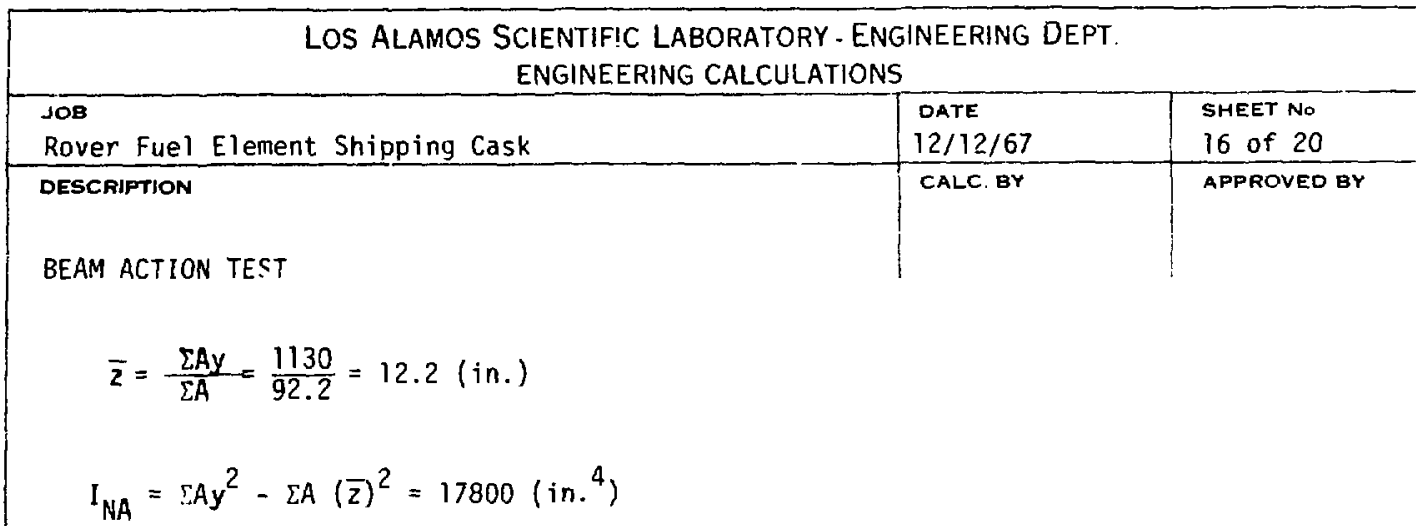

Extreme Fiber Stress

$$
\sigma_{\max }=\frac{M C}{I}=\frac{2205(38.25-12.2)}{17800}=3220(05 i)
$$

Conclusion

The strength of the steel jacket alone is more than adequate. A $\sigma_{\text {max }}$ of 3220 shows a M.S. (margin of safety) of -10 based on a $\sigma_{y}$ (yield stress) of 35,000 psi. 


\section{FREE DROP CONDITION}

$30 \mathrm{Ft}$. Drop to Unyielding Surface

\section{ASSUMPTIONS}

a. Loss of lid is critical

b. Maximum acceleration forcing lid to come off occurs when the longer edge strikes at $45^{\circ}$.

c. All energy absorption is due to plastic deformation of the lead

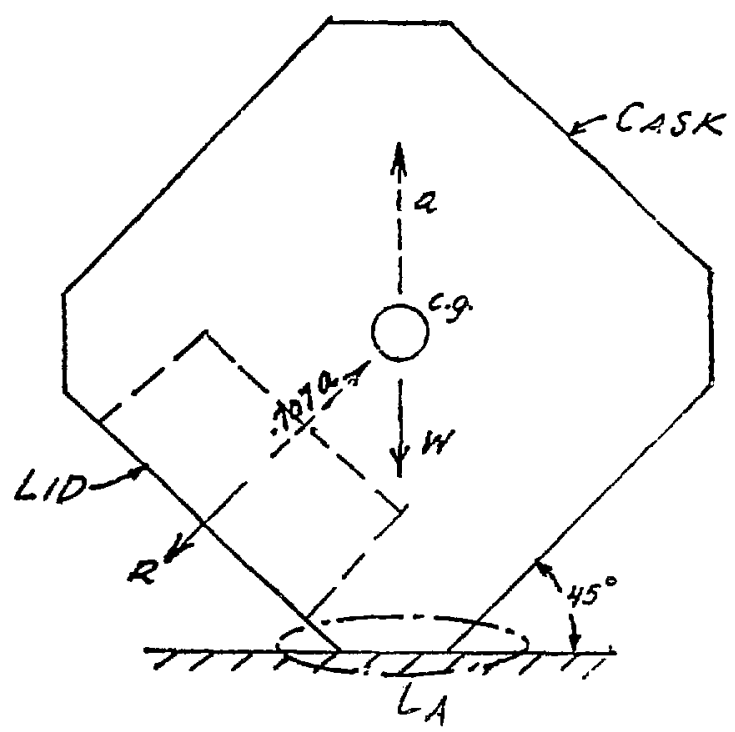

NOTE: 24 bolts hold lid in place:

$4(A 307)-3 / 4 "$ bolts each along the longer edges of the lid in the existing bolt pattern and $8(A 307)$ - 1 "boits each along the longer edges of the cask. 


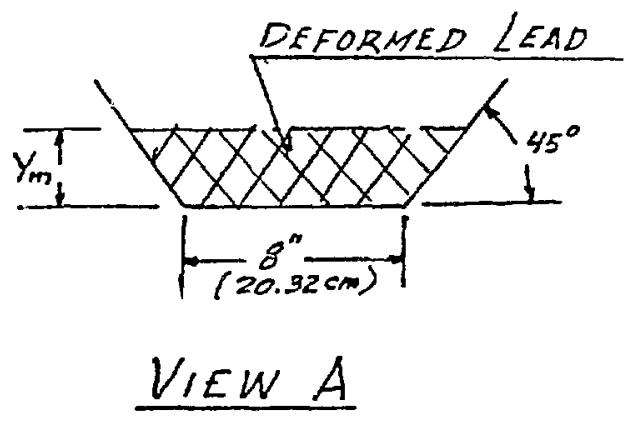

ENEREY IN DEFORMED LEAD

$$
\begin{aligned}
& E_{L}=\sigma_{Y} \cdot d V \\
& \sigma_{Y}=40001 \mathrm{~b} / \mathrm{in}^{2} \text { (Yield Strength) } \\
& V=\text { Deformed Volume } \\
& V=\left(Y^{2}{ }^{2}+8 \mathrm{Ym}\right) \mathrm{L} \quad(\mathrm{L}=\text { Length) }
\end{aligned}
$$

EQUATING DROP E:IEO:: TO ENERGY OF DEFORMED LEAD

$$
\begin{aligned}
& \left.\left(\mathrm{Ym}^{2}+8 \mathrm{Ym}_{\mathrm{m}}\right) 8 \mathrm{in.} 4000 \mathrm{lb} / \mathrm{in}^{2}=42800 \mathrm{lb} .30 \mathrm{ft} \times 12 \mathrm{in} / \mathrm{ft}^{+t}\right) \\
& 336 \mathrm{Ym}^{2}+2688 \mathrm{Ym}-15408 .=0 \\
& Y_{m^{2}}+8 Y_{m}-45.857=0 \\
& Y m=\frac{-8 \pm 64+183.428}{2} \\
& Y_{m}=\frac{-8 \pm 15.729}{2}=3.864 \mathrm{in} . \\
& A_{\max }=(15.729)(84)=1321.2 \mathrm{in}^{2}
\end{aligned}
$$


where, $A=$ Area

$$
a_{\max }=\frac{F}{M}=\frac{\sigma_{y} A_{\max }}{M}=\frac{4001 \mathrm{~b} / \mathrm{in}^{2} 1321.2 \mathrm{in}^{2}}{\frac{428001 \mathrm{~b}}{32.2 f / 5^{2}}}
$$

where,

$$
\begin{aligned}
& a=\text { acceleration } \\
& m=\text { mass and } F=\text { force } \\
& a_{c g}=3976 \mathrm{f} / \mathrm{s}^{2} \\
& R=M \cdot a
\end{aligned}
$$

where,

$R=$ Lid Component of Force

$R=\frac{l_{\text {Lid }}^{\prime}}{32.2}\left(3976 \cos 45^{\circ}\right)=\frac{6000(2811)}{32.2}$

$R=524000 \underline{1 \mathrm{~b}}$

$F /$ Bolt $=\frac{524000}{16} \quad 32350 \mathrm{LB}$ (Using 1 inch bolts onity)

\section{ASSUME LID P::OTS ABOUT O:IE EDGE}

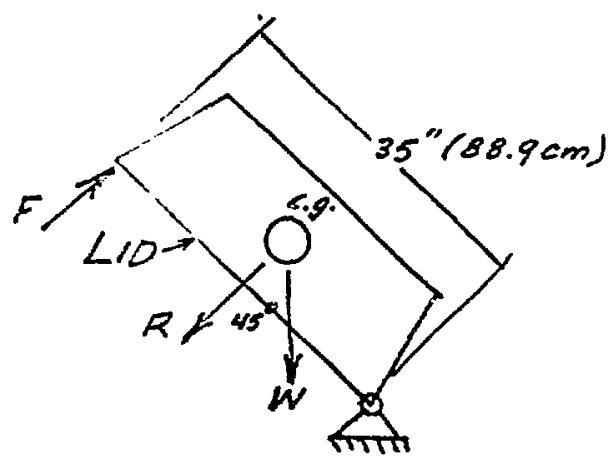


$\Sigma M_{0}=0 ; 6000\left(\frac{35}{2}\right)(.707)+(524000)\left(\frac{35}{2}\right)=F(35)$

$F=264000$

\section{F/Bolt 33000 LB}

Conclusion:

Because the minimum strength of a 1 " A307 bolt is 33350 lbs and the maximum calculated bolt load resulting from the 30 foot drop condition is $327501 \mathrm{bs}$, the $\mathrm{I}^{\prime \prime}$ bolt pattern furnishes ample strength to keep the lid on. 


\section{QUALITY ASSURANCE PROGRAM PLAN \\ 21-Ton Rover Fuel Cask}

This Quality Assurance Program Plan has been prepared and complies with the applicable sections of LASL Quality Assurance Manual for Fngineering and Construction, LA-5220-M, for a Type $I$ consequence-of-failure, and is in compliance with the U. S. Code of Federal Reguiations, Title 10, Part 71, Appendix E, "Quality Assurance."

The following program shall serve as a minimum requirement:

1. Design Control: A Project Engineer shall be designated for overall design control of the project. He shall prepare the design criteria for use by the designers. This design contxol shall include provisions for the following:

(a) Provisions for applicable codes and standards.

(b) Establishment of qualitative and quartitative acceptance criteria.

(c) Control of Engineering issued documents.

(d) Provisions for design verification by independent groups or individuals. (The Project Engineer can assign this function to the Design Review Board at his option.)

(e) To document this design control, a $10 \mathrm{~g}$ of each applicable item shall be maintained by the project Engineer. is $c$ minimum, logs shall be used fo: the fo: lowing items:

(1) Design Criteria (ENG-6)

(2) Design calculations (ENG-6)

(3) Construction or fabrication $\bar{\cdots} \cdot \cdots$ ings (ENG-z)

(4) Special processes or work proctinres (ENG-i.)

As each revision is made, the corresponding $\log$ stiaiz be updatec. The log shall be transmitted along with each revisior. Fne Project Engineer shall maintais a distribution list for $c$ is controllec item 
and each transinital sha2l regulec receipe acknowledgenent of the ites and the disposition of the superseded docuzent from the rectaient.

All revisions or ohanges shatl be handied in s maner consenturate with the original design control.

2. Docunent Control: Documente ofher thas thoce controlled afrecty by the Project Engincer shall be controlled by a cesignatcd dacumns controller (ENG-3), in a manner icientieal to those craloyed by bie project Engineex.

Document Control shall be apsicd to the following lectust

(a) Procurement docuinents

(b) Hork procedures frogared by groups other than the Project Engineer.

No document may be issued for sse on the projeet untid it has recedves the writen approval of the frojoet Engineer.

3. Procurement: so procurement setumts shall be relossed cor furchising

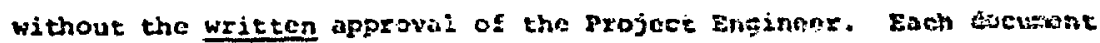
ohall contain the following minisur Infunition.
(a) Industriol standares to be thet
(b) Special reguircmonts, is necded, for handling, packaping, ote.
(c) Shop drawings an: : lex cesceiptive subiritals
(a) Catalogue inform: : :
(e) Instructions for : : : *ing inspection
(f) Control of noncon:ersing items.

The procurement document s!..: state if the cub-ticr contractors shall have their own Quality Assi.. . :e progran. Such prograns shall be approved by the Project Ens:: := and the List quality Assurance lic:i prior to any ordars being $\mathrm{F}_{2} .20$.

4. Fabrication: Fabrication sk,..11 be accomplished utilizing written procedures approved by the Pro:" st Engincer 25 follows:

(a) Helding procedure mecifications 


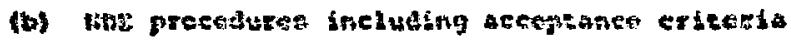

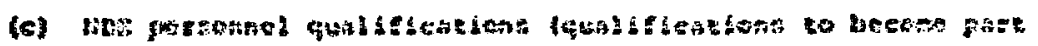
of the job trotat

(d) Insfictsen, Int

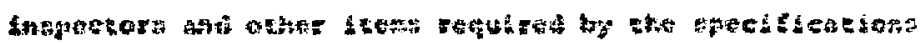

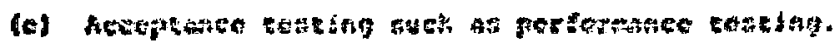

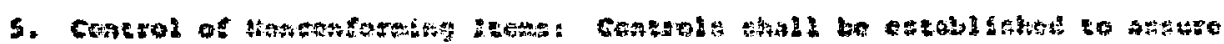

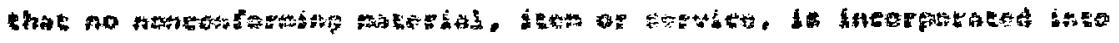

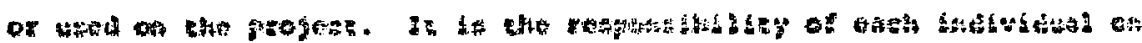

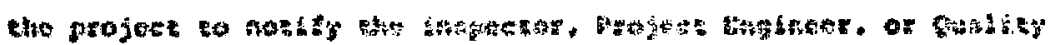

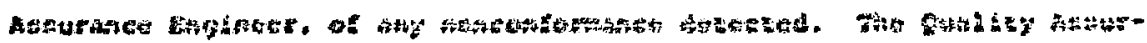

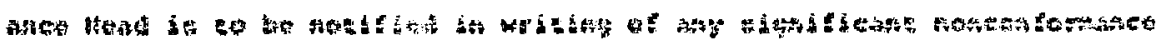

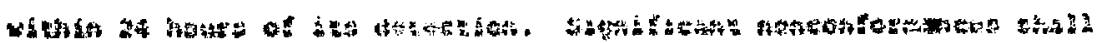

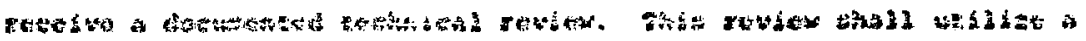
Q

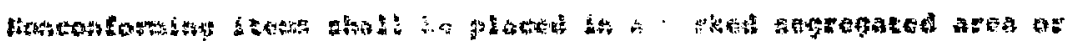

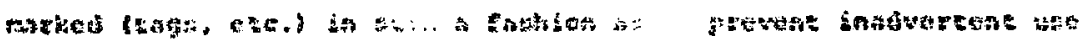

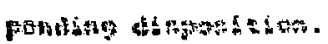

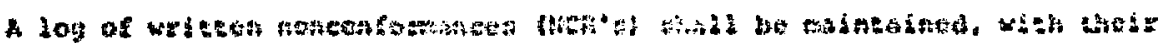

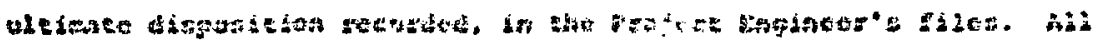

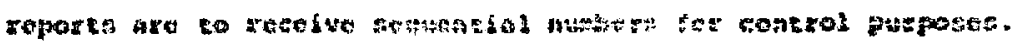

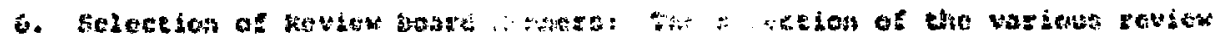

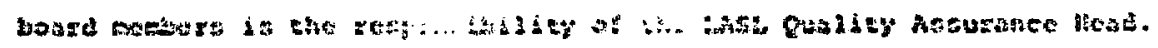

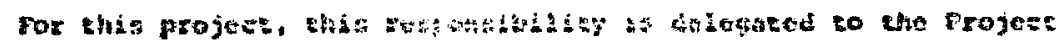

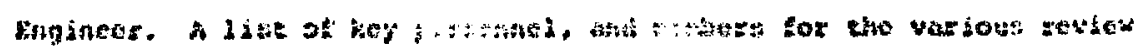

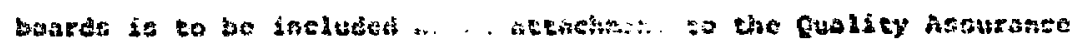
Progean.

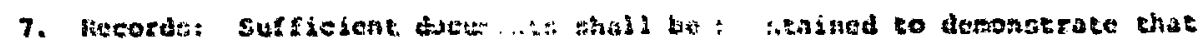

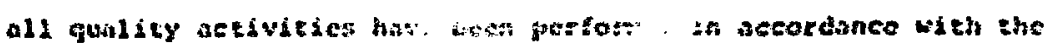

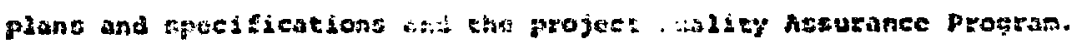
ficcords stall be stored in a woisture prin. Giro protected environisent. 
Tho following documents are to be stored:

(a) Dosign Criteria (ENG-7)

(b) Design Calculations (ENG-7)

(c) Fabrication and construction arasing (one copy of each revision issued) (EitG-3)

(a) Procurcment docunents (one copy of each revision issued) (ENG-6)

(c) Document control logs (ENG-6)

(f) Written prosedures and instructions (ENG-6)

(i) Personnel qualification recoras (SD-DO)

(ii) Honconformance Reports (ENG-7)

(i) As-built drawings (ENG-6)

(j) Msterial west Reports and Certificates of Compliance (SP-DO)

(i:) Records of any review board actions (ENG-7). 


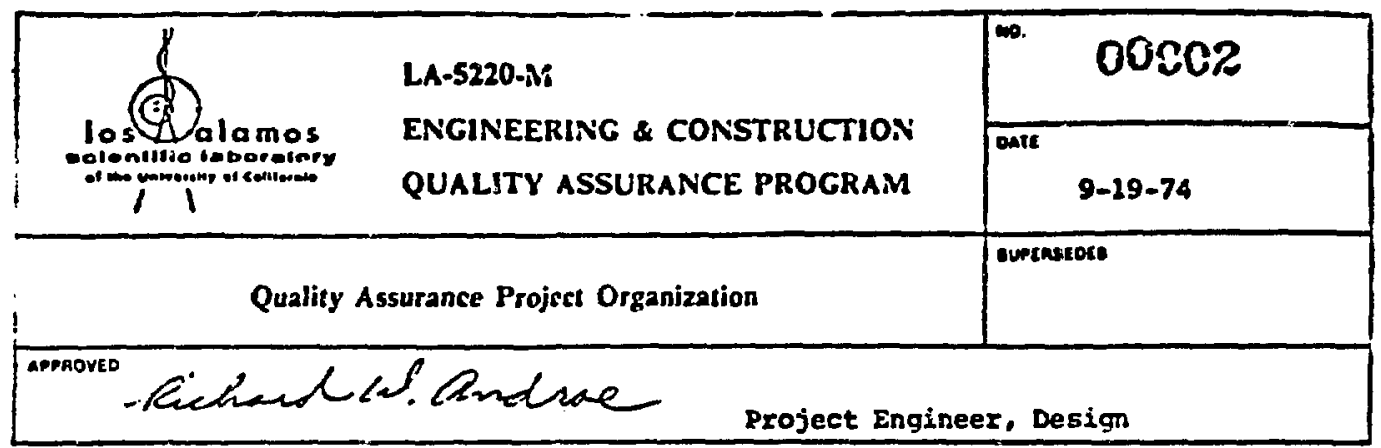

CMib-14 21-Ton Rover Fuel Cask (DOT SP 5645) L. J. 5216-0

$$
\text { PA.E_ } 1 \text { OF } 1
$$

Key Personnel

Operating Manager:

Project Engineer, Design:

John W. Schulte, C:B-14

Project Engineer, Fabrication:.

Richard W. Andrae, ENG-7

John W. MeMullen, ENG-6

\section{Design Review Boará}

David R. Snitr. .

Carl Bucklanc,

John W. Schuiz.

Betty Lobb

J. Bennie Montoya John K. Mckullen

Richard W. Asdrae

hilliam E. Stoclit
P-5

H-2

CMB-14

SP-DO

ENG-3

ENG-6

ENG-7

$\mathrm{H}-7$
Criticality

Health Physies

Radiation Shieldan:

Shippins

Records Maragemen:

Fabrication

Structural

Industrial Hygiens 


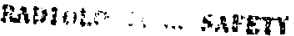

LOS ALAMOS SCIENTFIE LADORATOMY

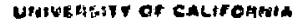

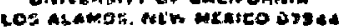

TCLerpose:

OFFICE MEMORANDUM

To

D. II. Smith, N-2

onte: March 8,1968

suBJECT. Shielding Calculations for a 200-Elcment Shipping Cask

SYMBOL: $\quad \mathrm{N}-2-8173$

A series of calculations has been made to evaluata the shielding provided by a 200-element shipoing cask. Of the criteria indicated, the value which limits the londing is the dose rate three feet from the lateral surface of the undamagud cask.

The geometry for tho base caiculation is indicated on Fig. 1. Table 1 gives the material densities associated fith the various regions. Densities inside the cask insert are intender to be representative of 200 Phoebus-type fuel elements in a matrix of borated phenolic. All elements were considered to have the same activity with a distribution function alone the length similar to the power density distribution durin: operation. The point-kernel program QAD (LA-35T3) was use! U. the calculation.

Gamma-ray source streneths were taken frc: dita to be published by Peterson, Graves, and Seale as 1.9902 . The particular spectrum employed is characteristic of $1 \times 10^{6}$ sec (11.6 days) after shutdown from a $3600 \mathrm{sec} \mathrm{(1} \mathrm{hr}$ ) reactor run. The results would not be significantly affected by the particular choice of exposure and decay time however.

\section{Table I}

Material Densities for Shipping Cas:

$$
\left(\mathrm{g} / \mathrm{cm}^{3}\right)
$$

Iden.

Material

\begin{tabular}{|c|c|c|c|c|}
\hline Hydrogen & Carbon & Iron & {$[\because \ldots \ldots$} & $\therefore \therefore$. \\
\hline .076 & 1.27 & .077 & $\therefore \because$ & - \\
\hline .10 & .90 & - & $\ldots$ & -- \\
\hline-- & - & 8.0 & -- & - \\
\hline$-\infty$ & -- & -- & -- & $12 \ldots$ \\
\hline
\end{tabular}




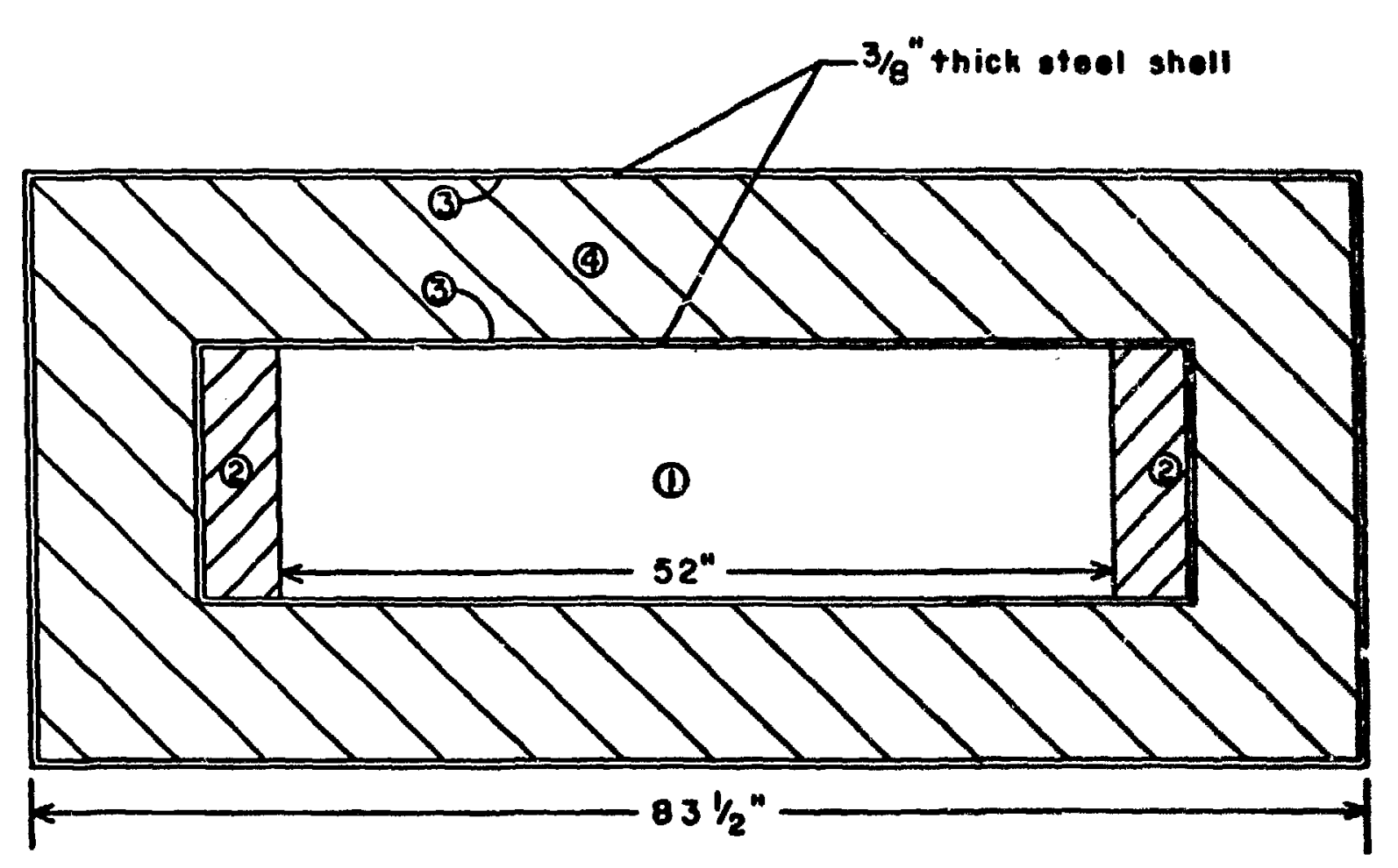

$a$
$\vdots$
$\vdots$
$\vdots$

Fig. 1

Configuration of undamaged Cask 
LOS ALAMOS SEENTIFIC LADORATORT univeasirv of cactronmia LOQ ALumos. WrW METice

เo: $\quad N-2-8173$

3.

DATE: March 8, 1968

Three configurations of the cask were considered:

1) the intact cask as indicated on Fig. 1 ,

2) the cask with $1 / 2$ inch of lead removed.

3) the cask doformed by a plane perpendicular to a line from the casic centor to an exterior corner such that the minimum thickness of lead reasining was 7.3 inches.

For configuration 1, the cask loadiniss to give $200 \mathrm{mr} /: \mathrm{r}$ in contact with the lateral and end surfaces and $10 \mathrm{mr} / \mathrm{hr}$ t: ree feet from the lateral and (nd surfaces were cetermined. Lordings to yield $1 \mathrm{r} / \mathrm{hr}$ three feet from the lateral and end sur:face were determined for the second configuration. For the thirc, the loading to give $1 \mathrm{r} / \mathrm{hr}$ three feet fron the deformed suriace was calculated. Results aro given in Table II. The limiting value for the cask is seen to be $1.1 \times 10^{3}$ watts or $1.9 \times 10^{5}$ curies, a value which bives $10 \mathrm{mr} / \mathrm{hr}$ three feet from the lateral surface.

is a check on the technique, values derived solely from calculation (as above) were compared with measurements. On April 10, 1967, 189 elenents from the Phoobus 1B run were shipped from NTS. According to Richard Davis, $J-?$, the monitor reported $<1 \mathrm{mr} / \mathrm{hr}$ at three feet and $\sim 2 \mathrm{mr} / \mathrm{hr}$ in -ontact with the cask. Data from the decay calcula: ions referenc : indicate $a$ source strength of 27.55 watts ( 4684 curies). The calculated results were $0.3 \mathrm{mr} / \mathrm{hr}$ at isree feet and $1.3 \mathrm{mr} / \mathrm{h}:$ in contact. Considering that the total attanuation of the eask is greater than $10^{5}$, the agreement is quite good.

The values given in Table II are specific to the cask and cask insert considered. As self-shielding was taken into account (and it must, to ge correct) an un-sel -5. ielded source of $1.9 x$ $10^{5}$ curies of $C^{60}$ would prisably give :. L ose rate ligher, perhaps by a factor of $5-10$, ti: $\mathrm{n} 10 \mathrm{mr} / \mathrm{h}:$ ti.ree feet from the surface of the cask.

I would be happy to elaboraie on additional details of the calculations if you consider it necessar:

KEH: jf

c: D. R. Snith, N-2 (3 copies;

J. D. Orridoff, $N-2$

G. A. Graves, $\mathbf{N}-2$

R. E. Malenfant file (6 copies) 
Table II

Source Strnnrths in ihtts and *Curies to Provide Dose Rates as Indicated

\begin{tabular}{|c|c|c|c|c|c|c|c|c|c|c|}
\hline \multirow[t]{2}{*}{$\begin{array}{l}\text { Config- } \\
\text { uration }\end{array}$} & \multicolumn{2}{|c|}{$\begin{array}{l}\text { Contact with } \\
\text { Iateral surface }\end{array}$} & \multicolumn{2}{|c|}{$\begin{array}{l}\text { Three Feet from } \\
\text { Iateral Surfece }\end{array}$} & \multicolumn{2}{|c|}{$\begin{array}{l}\text { Contact with } \\
\text { End Surface }\end{array}$} & \multicolumn{2}{|c|}{$\begin{array}{c}\text { Three Feet frod } \\
\text { End Surface } \\
\end{array}$} & \multicolumn{2}{|c|}{$\begin{array}{l}\text { Thrse feet from } \\
\text { Deformed Surface }\end{array}$} \\
\hline & $y$ watts & curies & $\underline{v \text { watts }}$ & curies & $Y$ watts & curies & $v$ watts & curies & $v$ waits & curies \\
\hline 1 & $8.2 \times 10^{3}$ & $1.59 \times 10^{6}$ & $1,1, n^{3}$ & $1.9 \times 10^{5}$ & $3.3 \times 10^{11}$ & 5.7 & $7 \cdot 5 \times 10^{3}$ & $1.3 \times 10^{6}$ & -- & -- \\
\hline 2 & - & -- & $5.5 \times 10^{3}$ & $9.4 \times 10^{5}$ & -- & - & $3.8 \times 10^{4}$ & $6.5 \times 10^{6}$ & - & -- \\
\hline 3 & -- & -- & -- & -- & - & $\infty$ & $-\infty$ & - & $1.1 \times 10^{6}$ & $1.2 \times 10^{8}$ \\
\hline
\end{tabular}

*The conversion from mtts of $y$ activity to curies was wade on the basis of an average enorgo per disintegration of I MeV. 


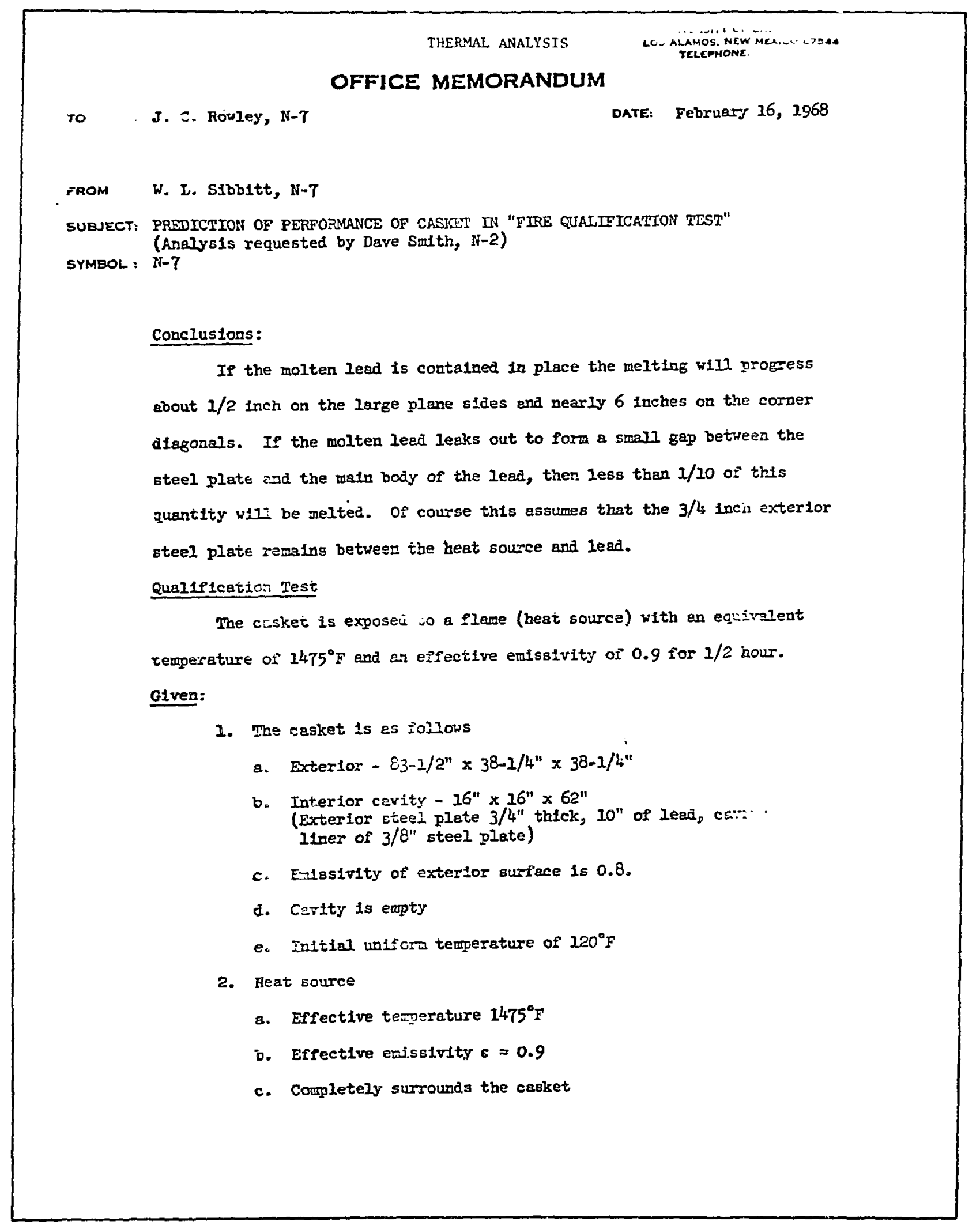




\section{To Prove}

That the efficacy of the casket has not been serlously inpaired at the end of the test. (Apparently this would mean that an appreclable portion of the lead must remain in place.)

\section{Assurutions:}

1. The "effective" heet source allows for all exterior heat losses from the casket. The view factar from the source to the sink is unity. Therefore the net heat radiated to the casket ralses the temperature of the material or melts the lead, 1.e., no heat is lost by convection or conduction to the surroundings.

2. The contact between the steel end the lead is periect, 1.e., It does not introajuce an eaditional zesistance to heat flow.

3. When the laed melts It zemains within the casket ari sets up convection currents such as to form a perfect ieat conductor (actur]ly ine conductivity of Ilguid lead is about I/2 that of sol1d lead). A.ll solid surfeces in contact with the meli remats clean. (This means that the maxi=:-a amount of lead w1ll be meltej.)

If the molten lead leaks out and leaves a smail gep ce-ween the solf: lead and the steel plate then the rate of heat flow will dec:sis to about $10 \%$ of the original value. However the $3 / 4 "$ exterlor steel ficis w1ll be at a wuch bigher temperature level $\sim$ about $1420^{\circ} \mathrm{F}$. 
Discussion of Heat Flow Phenoment

The heat flow can be considered as approximating three different cases :

Case 1 - One Dimenslonal Translent Heat Flow

This case is approximated at the center of the large plane siles. After 27 minutes from the start of the test the lead starts to melt. After 30 minutes the maximum amount of Iead which could be melted is 1.28 inches the amount whist actually would melt is ebout 0.5 inch. Thus a maximum of $12.8 \%$ of tine lead could melt but probably only 5\% would melt (the belt wust remain in contact with the solld surfeces). Crne 2 - Two D1wenslonel Translent Heat Fiow This case is epproximated by $z: z$ edges (Far renoved I. . I the comers). In this case the -10 starts to melt in 23.9 mutes and after 30 minutes about $40 \%$ or the lead is molter. Ir Ferws of an analogous siab this amouncs to about 2 inches of Eiten lead. Actually a little more lesd would melt on the Do: com edges than on the top edges.

Ca:s 3 - Three Dimensionel Transiest Heat Flow

This case is approxtmated in the elght corners. In $18: 3$ mizutes the lead w1]l siart to meli. In 30 mlautes the melt will hare progressed about 5.84 inches along ti.e comer diagonal. 
Case 4 - Lead Exposed Directly to the Heat Source

If the $3 / 4$ " exterlor steel plate vere removed such as to expose the lead afrectly to the heat source the times required to reach the melting point of the lead would be about the same as prevlously computed. Since the lead surface vould probably be dirty yith an emissivity of about 0.65 (this corresponds to a heavily oxidized surface). As soon as the lead melts and the molten lead runs down the emissivity of the surface cecreases to about 0.06 thus the heat flux would decrease to $9 . \mathrm{al}^{4} \mathrm{p}$ of the initial value. If we assume no heat loss to the interior of the casket (maximum melting rate) thea this corresponds to less than 2 inches per hour.

\section{Summery:}

Th1s anelysis yas based on est1-ating the maxtr:: amount of lead wh1ch could be welted. If some of the melt leaks out then the rate of heat flow to the massive solid lead winl be drastically reciced.

The white pafnt on the casket has a reflectirity of about $5 \%$ for the long vave lengths corresponding to th $=1475^{\circ} \mathrm{F}$ source. Aluminum paint bas a reflectivity of $70 \%$ in this same wave icogth regics. In addition aluminum ppints vith silicone base are touted ficr temperatures up to $1200^{\circ} \mathrm{F}$.

\section{F. 2. S1bbitt}

WIS:do

Distribution: 


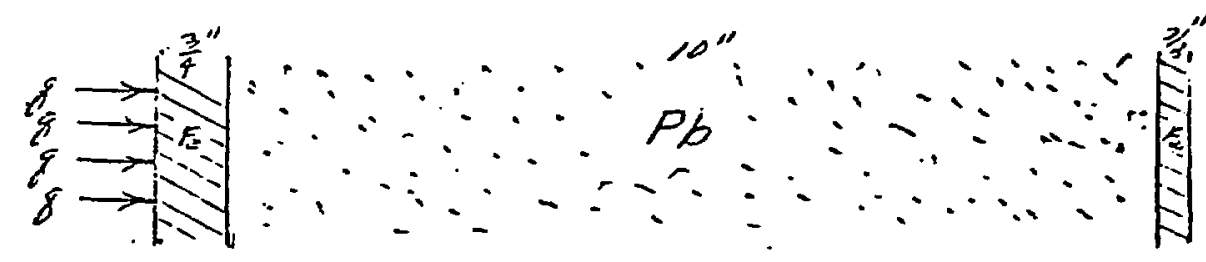

Case 1 Plane Wall

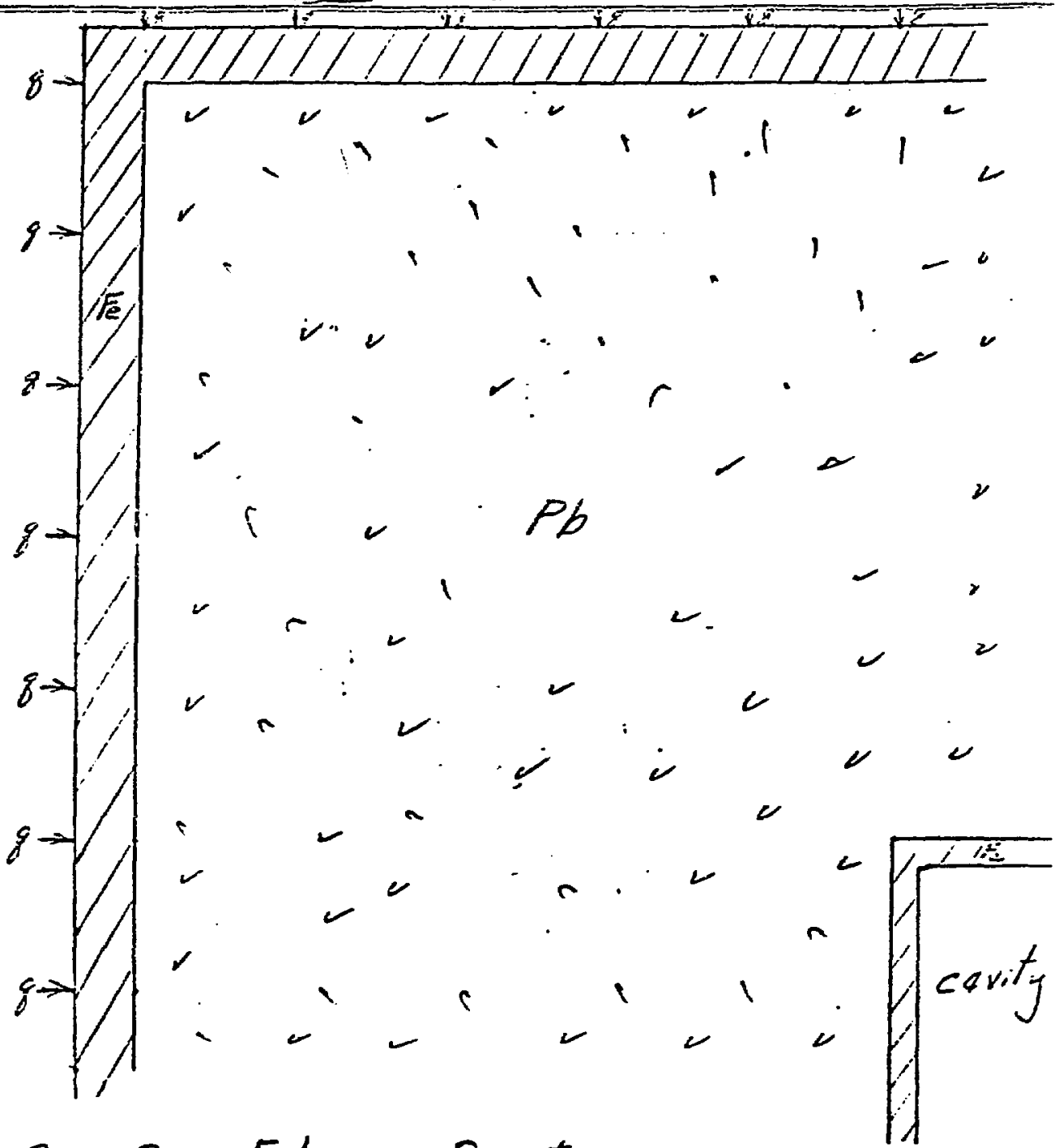

Case 2. Edge Section 


\author{
LOS ALAMOS SCIENTIFIC LABORATORY \\ UNIVERSITY OF CALIFORNIA \\ LOS ALAMOS. NEW MEXICO 87540 \\ OFFICE MEMORANDUM \\ To : H. E. Noyes, SP-DO \\ DATE: September 17,1974 \\ FROM : D. R. Smith, P-5 A...
}

SUEJECT . Nuclear Sa Tory IIC Irradiated Fuel

SYMBOL : $\mathbf{P - 5}-447$

Fuel srom the Rover and Tory IIo reactors, currently stored at Jackass Flats, Nevada, is to be shipped to the Idaho Chemical Processing Plant in the LASL Rover casks which were granted DOT Special Permit 5645. The proposed shipping configurations have been evaluated using the DTF 71 transport code and the KENO Monte Carlo code. Results demonstrate that these conigurations comply with Fissile Class I criteria.

Fuel is to be shipped in a Cask Insert Box which has been designed by Avery Bond, $J-6$ (NTS), and is shown on his drawings $31474 \mathrm{Dl}$ through $\mathrm{D} 7$. The $54 "$ long insert consists of a 5x5 square array of $3^{\prime \prime} 0 . d . \times 0.620 "$ wall steel tubes in a welded aluminum box. The regions between the tubes are packed with boron carbide and sealed at each end by a poured epoxy plug. The twenty-iive steel tubes may be loaded with Rover iuel in cardboard tubes or Tory IIC fuel in welded aluminum tubes. These inner arrangements are both :or the convenience $0:$ the procassing plant; the Rover îel will go into an incinarator while the Tory IIC inel starts it's reprocessing in a dissolver.

The 2;" o.d. cardboard tubes may contain up to seven Rover fual elements. For purposes ot this criticality sarety evaluation it was assumed that the tubes were îlooded with water, and the fuel and water wele homogenized. All îel was assumed to contain $600 \mathrm{~kg} / \mathrm{M} 3$ of enriched uranium. The entire cask was defined in a KENo problem, with the boron carbide assumed to be at inalf theoretical density. Using 16 group Hansen-Roach cross sections, this problem was run for seventeen batches of 3CO neutrons each. Neglecting the irst threa batches, the resulting value $0 \mathrm{t}^{\prime} \mathrm{k}_{\mathrm{z}}$ was "olind to be $0.166 \pm 0.002$.

A second coniguration was investigated in a similar manner. Here the fuel was homogenized only with the water that would occupy the holes in the elements, ard tine remainder of the water within the tube served as an arinular reflector region around the iel zone. Surficiant batchas were processed for this configuration to demonstrate that it was less reactive than the "irst. 
LOS ALAMOS SCIENTIFIC LABORATORY umiveratTr of CALIFOHMIA

TO:

H. F. Noyes

2.

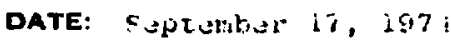

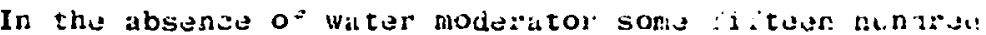

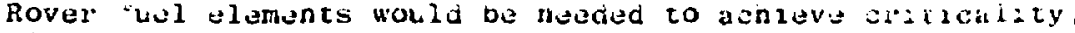
ince the insart box has provision for only $17 j$ elenients, tha unmoderated cask would be iar stoeritieal aven watrotit the boron carbida.

The aluminum twbes for tha Tory II are as yot l.nde ines, so Tory tuel was assimed to $: 11$ the $3 "$ stuel tubes 0 thd insert hox. Whatever size alumim.dn ube is onosen wall restilt in a less reactive cont'iguration than tint whi in was calevlated. The steel tube was sirroulded wath an ajpropriate volume 0 : boron carbide, again at hal deluszty. The outer boindary of the boron varbide was spiciades as a relecting stirace, so that tho Drf cell caldiation would provide a vaile of the miliplication sactor indicative $0^{\circ}$ an ininite arlay. The it approximalion was t:sed, again with lo group Hansen-Roach cross sajtions. "'hlla the Tory wel has $\mathrm{VO}_{2}$ loadings srom abolt $1.25^{\circ}$ to $6.12 \%$, all juel was asstimed to have the higher loading. The maximim volume fraction occlpied by luel was assumed to be 0.5 , and iull and partial tlooding wera considered.

Resilts tabulated below indicate that an in inite array or these cells wolid be substartialiy subcritical at any achiavable moderation.

Volume iraction

$\begin{array}{lcc}\text { fuel } & \text { water } & k_{\text {m }} \\ 0.5 & 0.0 & 0.225 \\ 0.5 & 0.2 & 0.282 \\ 0.5 & 0.5 & 0.513 \\ 0.3 & 0.7 & 0.490 \\ 0.2 & 0.8 & 0.430\end{array}$

The low value of $k_{e} ;$ obtained for the cask containing Rover tuel, coupled with the thickness of lead in the cask walls ( $11^{\prime \prime}$ ) provides gonfjdence that an infinite array o:" these loaded casks would be subcritical, while the cell calculations show the same or the Tory cuel.

This cask, loaded with Rover or Tory Euel in the Cask Insert Box, wili comply with Fissile Class 1 criteria.

DRS: $a \hat{i}$

C: $H$. . S. Noyes, SP-DO

A. L. Bond, $\mathbf{j}-\mathbf{t}$ NTS

"m. Morrison, $\wedge \mathrm{CC}$

K. E. Elliott, \&LO

P-DO

C. Bromley, NVO

D. R. Smith, P-5

Neal Powe? I, ID

Biail \& Records, 2 


\section{LOS ALAMOS SCIENTIFIC LABORATORY UHIVERSITY OF CALIFOAMIA LOS ALAMOS. HEW MEXICO BTSE \\ OFFICE MEMORANDUM

D. R. Smith, P-5 M

suesect. Nuclear Safety - Neutron Absorbing Inserts for the Rover Cask

SYMEOL P-5-509

Severa: cask insert designs have been used with the Rover casks. Early inserts were fabricated from aluminum and had a capacity of 100 elements. Strips of boral were placed in the interstitial regions, with the quantity of boron more than twice that calculated to provide an infinite multiflication factor less than unity. Two of these inserts could be loaded into each cask. The so-called "miniserts" were of similar construction but held only 25 elements.

A less costly insert was developed later, and consisted of boron loaded Epon plastic (LASL specification J9L-68-159) poured into the desired shape. The nominal boron content of the plastic was in excess of fifteen atom percent, and again was calculated to provide subcriticality for an unlimited accumulation of loaded inserts.

During 1963 measurements were performed in Kiva 2 of the Los Alamos Critical Facility to provide confidence in the safety calculations used for the design of inserts. An array of 380 one-inch diameter lucite tubes was loaded into the Tank geometry. This was a $20^{\prime \prime}$ square box positioned in a large tank that could be filled with water. Control and safety rods were located on two of the outer surfaces of the inner tank. The plastic tubes were loaded with Rover fuel elements of the type used in the $\mathrm{B}-4$ reactor. The average fuel element loading was approximately 320 $\mathrm{mg}$ uranium $/ \mathrm{cm}^{3}$, or about $120 \mathrm{~g}$ uranium per element. Plastic rods were placed in the regions between the plastic tubes so that the inner tank contained $45.4 \mathrm{~kg}$ of uranium at a carbon-to-uranium atom ratio of 108 and a hydrogen-touranium atom ratio of 14.3 . Some 35 boral strips were needed to keep this loading subcritical when fully reflected by water, or about $1 / 10$ the number provided in the cask inserts. These measurements resulted in increased con$f$ idence in the transport calculations which were used to specify boron loadings for the cask inserts. The allowable fisstle material loadings for both the plastic loaded insert and the insert containing boral strips was specified as $30 \mathrm{~kg}$ $235 \mathrm{U}$ per 100 element insert or $60 \mathrm{~kg}$ for the cask loaded with two inserts. 
LOS ALAMOS SCIENTIFIC LABORATORY

UNIVERSITY OF CALIFORNIA

LOS ALAMOS. NEW MEXICO ETBAA

ro: Betty Lobb $\quad 2 \quad$ DATE: November 21, 1974

It is assumed that twice as much boron would be needed to compensate for plutonium or uranium 233 when these materials are present, so the maximum loading of these materials is specified as $30 \mathrm{~kg}$. For mixed loadings the mass of uranium 235 divided by $60 \mathrm{~kg}$ plus the sum of the plutonium and uranium 233 masses divided by $30 \mathrm{~kg}$ should not exceed unity.

As boron loadings for all cask inserts have been specified on the basis of an infinite array of inserts being subcritical at the optimum achievable moderation, a loaded cask will comply with Fissile class I transport criteria.

DRS: a f

Distribution:

B. Lobb, SP-DO

John Schulte, CMB-14

A. L. Bond, J-6-NTS

P-DO

D. R. Smith, P-5

Mail \& Records, 2 
MATERIALSPECIEICATIOH

BOROII XYPREGIATEDPIASTIE

J-9L- $63-159$

Imogered by: J. W. Eow:

January 9, 2968 
A'tphane $505299-2731$

\section{TestFab Materials and Engineering Co. \\ 9718 Trumbuil Avenue, SE Albuquerque, New Mcxico 87112 \\ suritst 27, 1903}

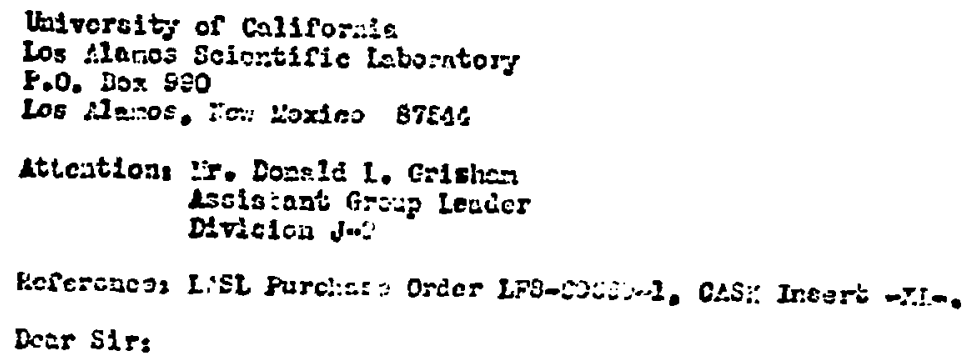

This letter is in regar.: to your rosish roguast for inforaditon

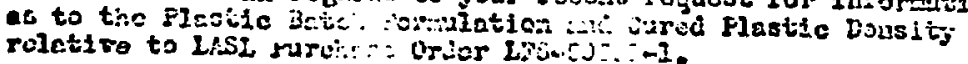

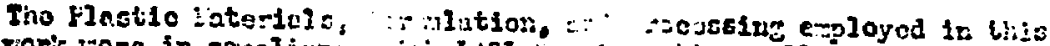

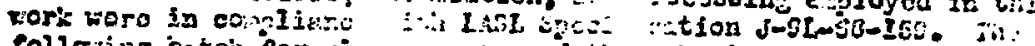

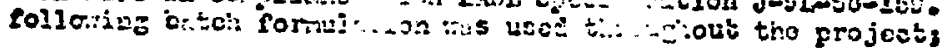

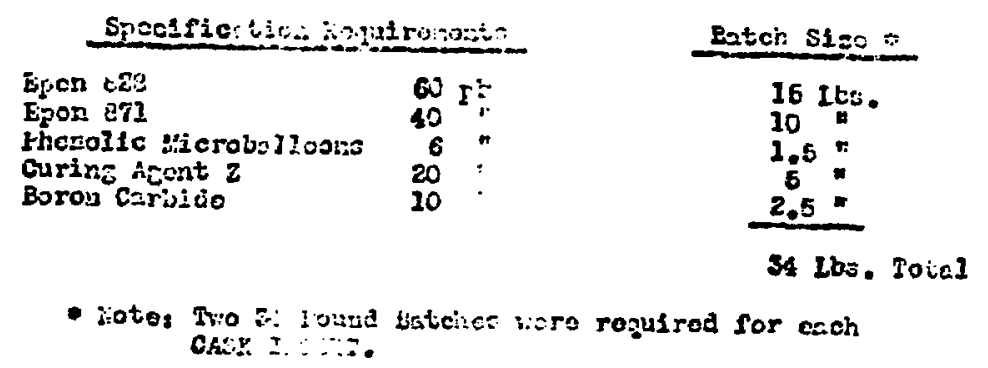

The Cured Flastic Deas: deteruinud us ing exess?. Itis: fr. ihe abovo Pornulation was This dersity ros fougd : $\because$ Ire- : Erocucticn potín: ojoricion. ie ers elso andosine $c$ :

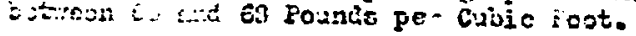
$=$ f the Alu: :.val yotal Cortirications.

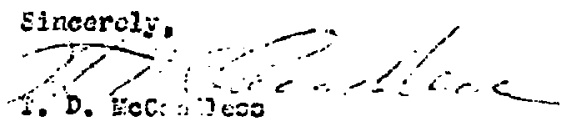

$20 ; \therefore=\pi$

ce: Ir. Jac: house, Div. Jue. 
Josing 1,1096

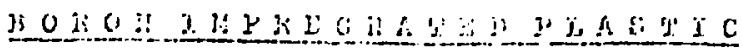

\section{Min:}

Fom 8

Jjon oil

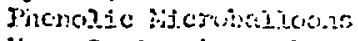

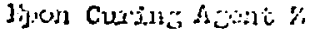

bion Caroje 3ing y

60

1,6

20

130

Process as follon:

1. Combine $1 p$ os 80 and rpon 871 resins.

2. Pronces to $2 ! 60^{6}:$

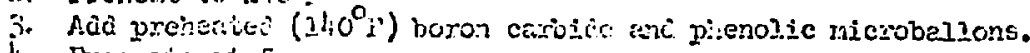

i. Evasuate at 5 r.h norcurs.

5. Rehert or cool as recissary io stubiline terperature of mixture at $160^{\circ} \mathrm{I} \pm 5 \%$.

6. Adr? Curing Escat. \% (roon tenperature).

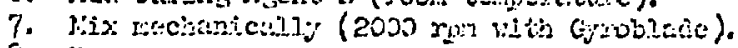

8. Evacuetie.

s. Jour casting;

10. Cure if hoiles at $120^{\circ} \mathrm{F}$, phus 2 hours at $260^{\circ} \mathrm{F}$, plus 2 howrs at $250^{\circ} \mathrm{F}$.

f. Iost cure with an aciditional $300^{\circ} \mathrm{p}$ cycle ney te desirable.

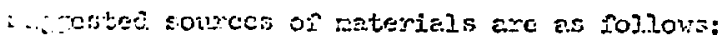

ing

Sholl Chancal Coras:

plastics ano irsins Division

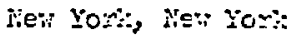

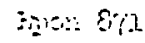

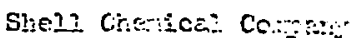

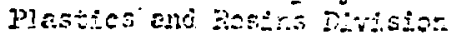
jick Zoxi, ther you:

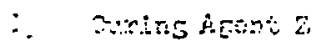

Shet? Chenicel cong=m

Plestics and kesire zivision Joy Yor, jev Yor:s

$\therefore \quad$ Zic Ycrotanons, $18.7 \mathrm{lbs} / \mathrm{rt}^{3}$

Plestics Divisin

Union cericice Corp.

Ios trater, Ce? íania

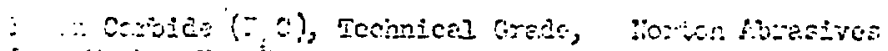

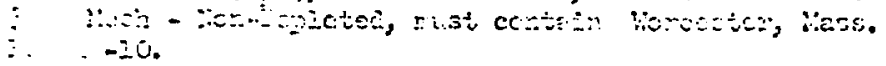




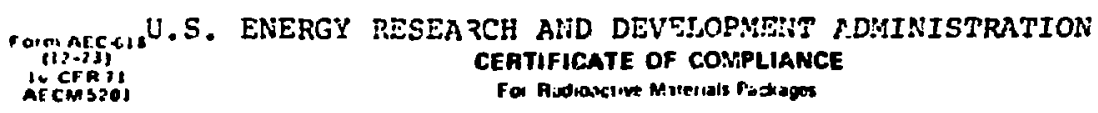

\begin{tabular}{|c|c|c|c|c|}
\hline $\begin{array}{l}\text { 1a. Certilieste Number } \\
\text { USA } 5645 / \text { BLF (ERDA-AL) }\end{array}$ & $\begin{array}{l}10 \text { Revesunto. } \\
\text { Oricinal }\end{array}$ & $\begin{array}{l}\text { Ic Packiga ldentificatuon No. } \\
\text { AL-L, } 8\end{array}$ & $\begin{array}{c}\text { 1c. Pige Ne. } \\
1\end{array}$ & \begin{tabular}{|c} 
1e. Total flo. Pages \\
2
\end{tabular} \\
\hline
\end{tabular}

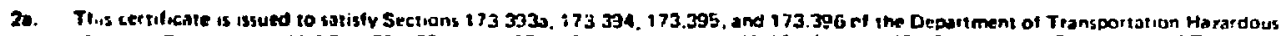

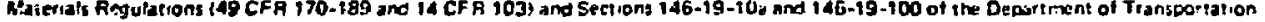
Dangerous Cargons Fegulalions (46 CFA 146-149). as amenoed.

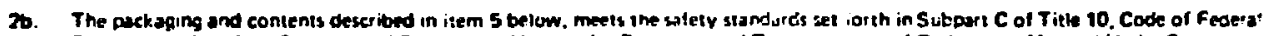

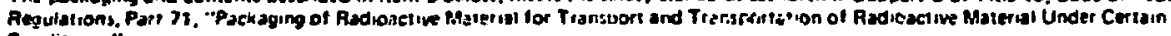
Conditions.:

2c. This ce:tilieate ding not relieve the tonsignos from compliancs with any resulrentent of ths regulations of the US. Department of

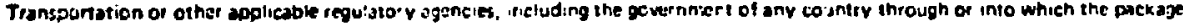
wili be tronstrotect.

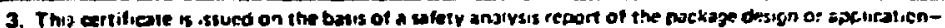

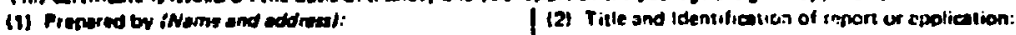

Los Alamos Scientific Iaboratofy of the University of Californil Los Alamos, New Mexico 87544

LA-5834-MS

Rover Shipping Cask by

Betty Lobb, Horace E. Noyes, and David R. Smith

\section{Conditions}

This cernfieate is conditianal upon the futtiling of the reuuirements of Subpars D of 10 CFR 71, as spplicable, and the conditions specrfied in them 5 betow.

3. Description of Packiging and Authorized Contenis, Wodel Number, Fmile Class, Other Conditions, and References:

The Pover casr is a rectangular, lead filled, steel jacketed we dmert which provices a ter-inch thick lead shielding contained in a $3 / 8$ inc:. stee jacket. Outer aimensions are approximately $85^{\prime \prime} \times 38^{\prime \prime} \times 38^{\prime \prime}$. The inner ca::iY dimensions are $62^{\prime \prime} \times 16^{\prime \prime} \times 16^{\mathrm{N}}$ anc the gross weight is approximately 21 tons.

The cask insert is 54" long and consists of a $5 \times 5$ sguare array of $3 "$ O.D. steel tubes in a welded aluminum box. The reçions between the tubes are packed with boron carbide and sealed at each end by a poured epoxy ing.

\section{Authorized Contents}

Allowable contents include Rover and Tory IIC elements and o:he: fissi: and radioactive materials in special form. When used for shipment of r:cze than fifteen Rover fuel elements all loaced elemerts will be in borc. poisoned cask inserts. Fuel elements not in these inserts will be encapsulated to comply with special form criteria.

Fast reactor fuel pins may be packaged in an insert consisting of a single length of five-inch diameter schecule 40 steel pipe with threaced or silastic gasketed flanged clcsure, The total fissile material loadinc Eor this configuration will not exceed 75 grans per om of pipe length

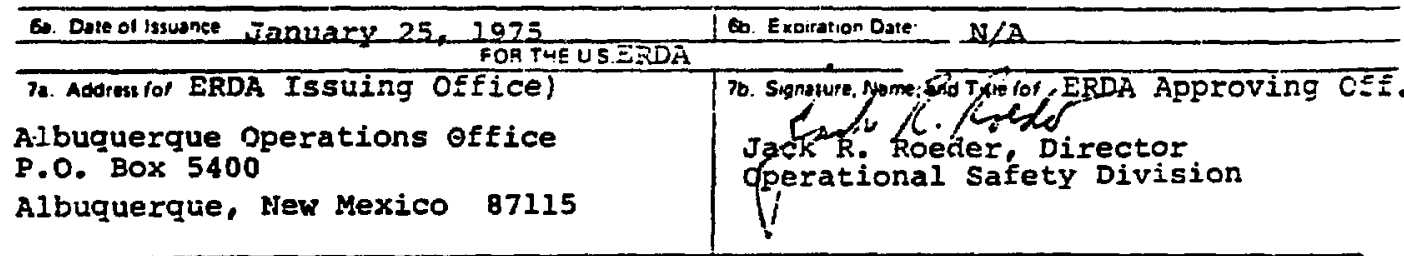


For the shipment of uranium 233 or plutonium-bearing material, the atomic ratio of boron to uranium 233 or plutonium will be at least twice the ratio of boron to uranium 235 normally Erovided for the lcaded Rover fuel element cask inserts, which is a factor of two yreater than calculated to provide a ko less than unity.

These considerations dictate a maximum of $60 \mathrm{~kg}$ of uranium 235 or $30 \mathrm{k}$ of uranium 233 or plutonium. Mixtures of fissile materials snall be so limited ihat the number of kilograms of $235 \mathrm{u}$ divided by 60 , plus the number of kilograms of plutonium and $233 \mathrm{v}$ divided by 30 will not exceec unity.

Shj.pments made using above criteria will meet Fissile class I requirements. 


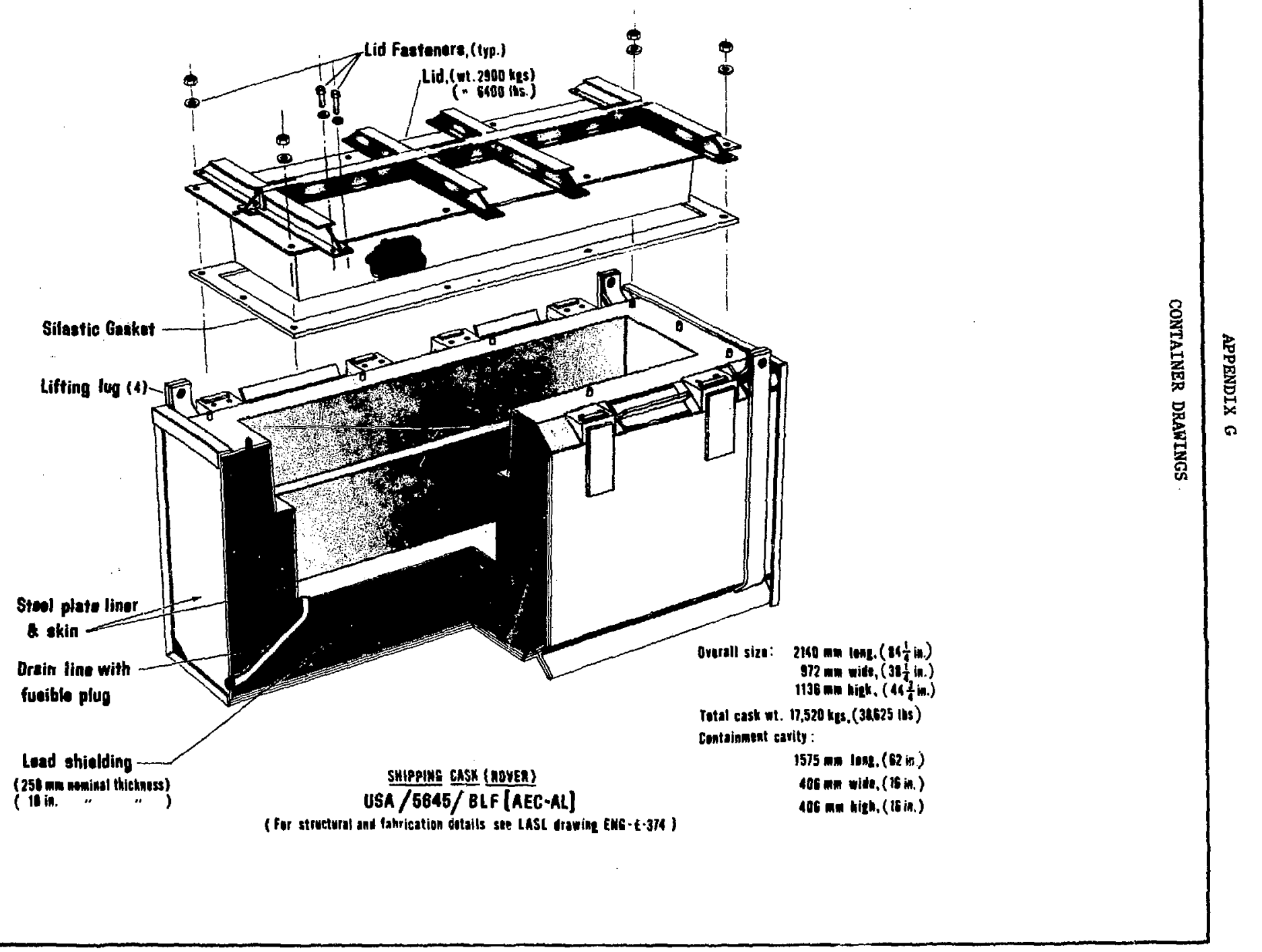




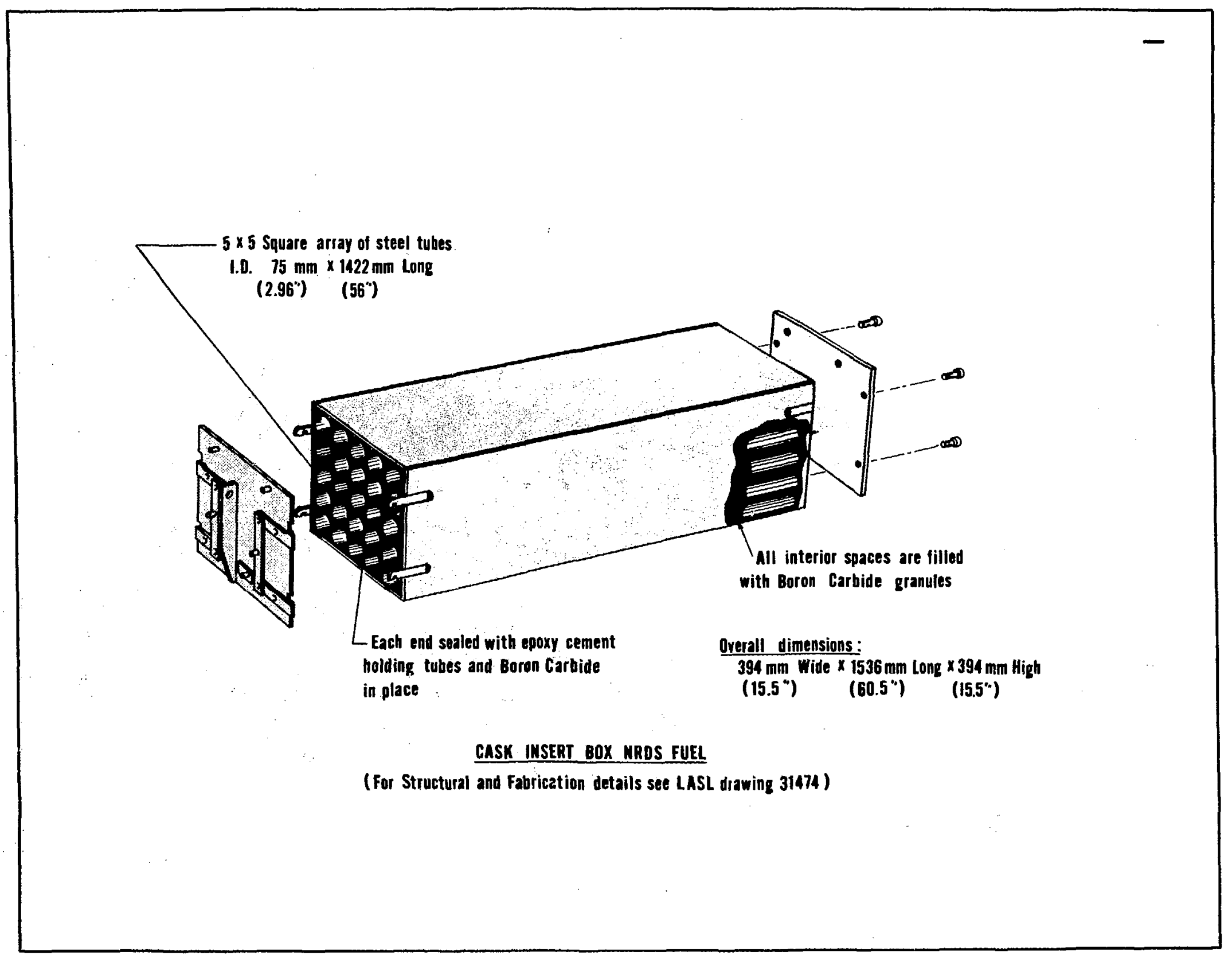




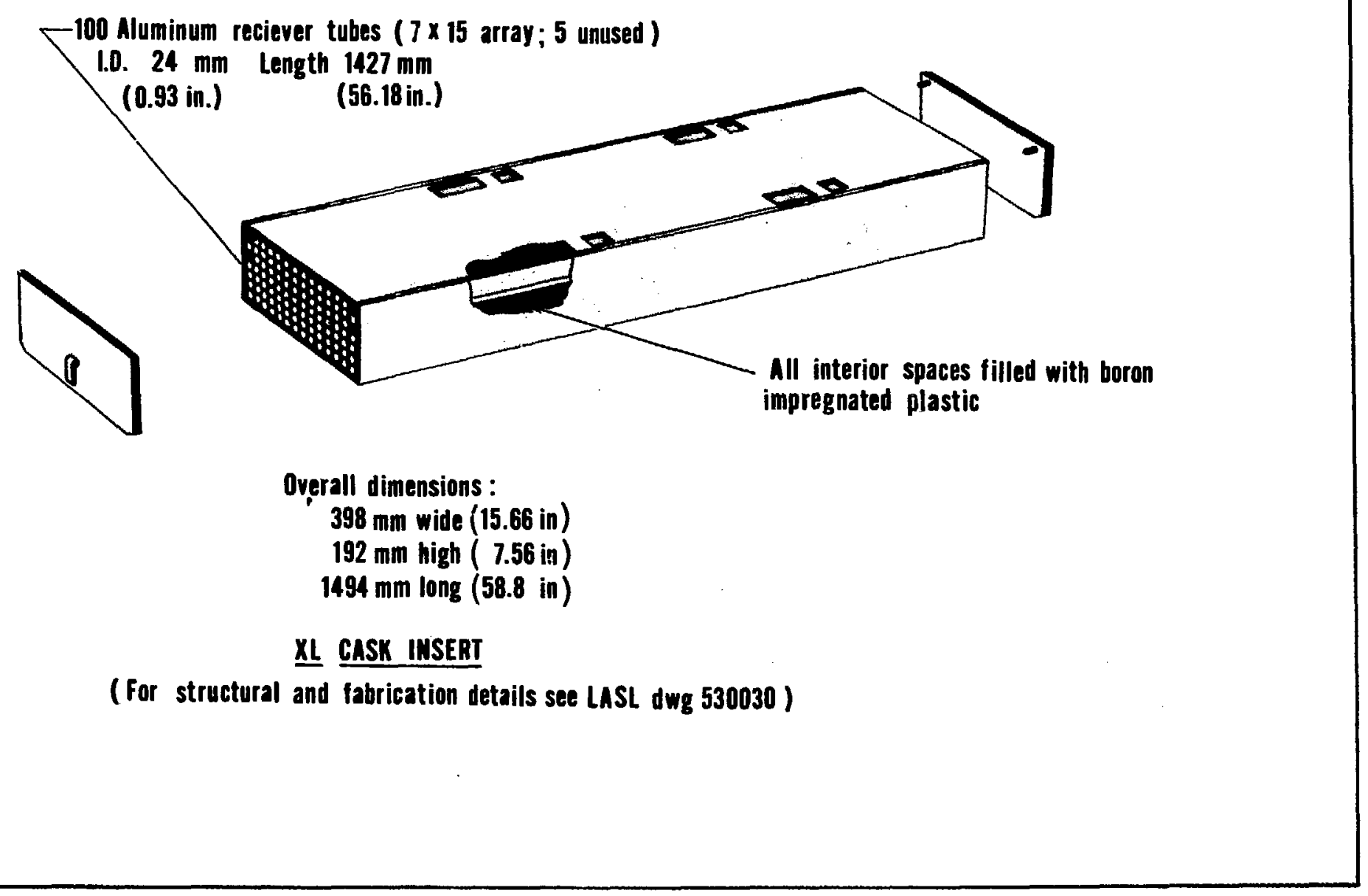

